\title{
Geochemistry and petrology of selected sediments from Bukit Song, Miri, Sarawak, Malaysia, with emphasis on organic matter characterization
}

\author{
Amin Tavakoli ${ }^{1,2}$
}

Received: 21 June 2021 / Accepted: 22 August 2021 / Published online: 29 August 2021

(c) The Author(s) 2021

\begin{abstract}
The aim of this study is to provide a better understanding of the type of source input, quality, quantity, the condition of depositional environment and thermal maturity of the organic matter from Bukit Song, Sarawak, which has not been extensively studied for hydrocarbon generation potential. Petrological and geochemical analyses were performed on 13 outcrop samples of the study location. Two samples, having type III and mixed kerogen, showed very-good-to-excellent petroleum potential based on bitumen extraction and data from Rock-Eval analysis. The rest of the samples are inert-kerogen type IV. In terms of thermal maturity based on vitrinite reflectance, the results of this paper are akin to previous studies done in the nearby region reported as either immature or early mature. $\mathrm{Ph} / n-\mathrm{C}_{18}$ versus $\mathrm{Pr} / n-\mathrm{C}_{17}$ data showed that the major concentration of samples is within peat coal environment, whilst two samples were associated with anoxic marine depositional environment, confirmed by maceral content as well. Macerals mainly indicated terrestrial precursors and, overall, a dominance of vitrinite. Quality of the source rock based on TOC parameter indicated above $2 \mathrm{wt}$ \% content for the majority of samples. However, consideration of TOC and $\mathrm{S}_{2}$ together showed only two samples to have better source rocks. Existence of cutinite, sporinite and greenish fluorescing resinite macerals corroborated with the immaturity of the analysed coaly samples. Varying degrees of the bitumen staining existed in a few samples. Kaolinite and illite were the major clays based on XRD analysis, which potentially indicate low porosity. This study revealed that hydrocarbon-generating potential of Bukit Song in Sarawak is low.
\end{abstract}

Keywords Hydrocarbon generation $\cdot$ Bukit song $\cdot$ Source rock $\cdot$ Biomarkers

\section{Introduction}

The study area is at Bukit Song (Fig. 1), approximately $2.4 \mathrm{~km}$ north-east of Lambir Hills National Park, and is part of the Lambir Formation of Miri zone in Sarawak, Malaysia. The Lambir Formation predominantly consists of sandstone, shale and some limestones, occupying relatively gentle synclines with little diagenetic changes (Hutchison 2005).

Stratigraphically, Lambir Formation is between Setap Shale Formation at its base, and Tukau and Belait

Amin Tavakoli

rmn_m@hotmail.com

1 Department of Geology, Faculty of Sciences, University of Malaya (UM), Kuala Lumpur, Malaysia

2 Present address: Department of Chemical and Environmental Engineering, Faculty of Engineering, Universiti Putra Malaysia (UPM), Serdang, Malaysia
Formations to the uppermost part (Fig. 2). To the southwest is the West Baram Line which is the position of a major stratigraphic change in the Middle to Late Eocene. The Lambir Formation has a maximum thickness of $1600 \mathrm{~m}$ (Hutchison 2005) and covers approximately $570 \mathrm{~km}^{2}$ in the Lambir Hills, Bakong area, Teraja area, and SE Marudi (Haile and Ho 1991), and it has no subdivisions. The Lambir Formation's depositional environment is mainly described as coastal to shallow delta (Hutchison 2005).

The Late Eocene and younger stratigraphy of the Miri Zone mainly consist of molasse deposits developed from the erosion of thrust sheets whilst uplift and deformation still progressing (Hutchison 2005). The strata of Miri were deposited in non-marine to relatively shallow (inner neritic) marine conditions where local unconformities are common due to extensive thin compressional tectonics (Hutchison 2005).

Almost all hydrocarbon-rich sedimentary basins of Malaysia and a few other regions of South East Asia began 
Fig. 1 The study region at Bukit Song is located at the North Western part of Borneo. The coordinates and whereabouts of the collected samples with respect to each other on the map are shown. Source: Google Maps

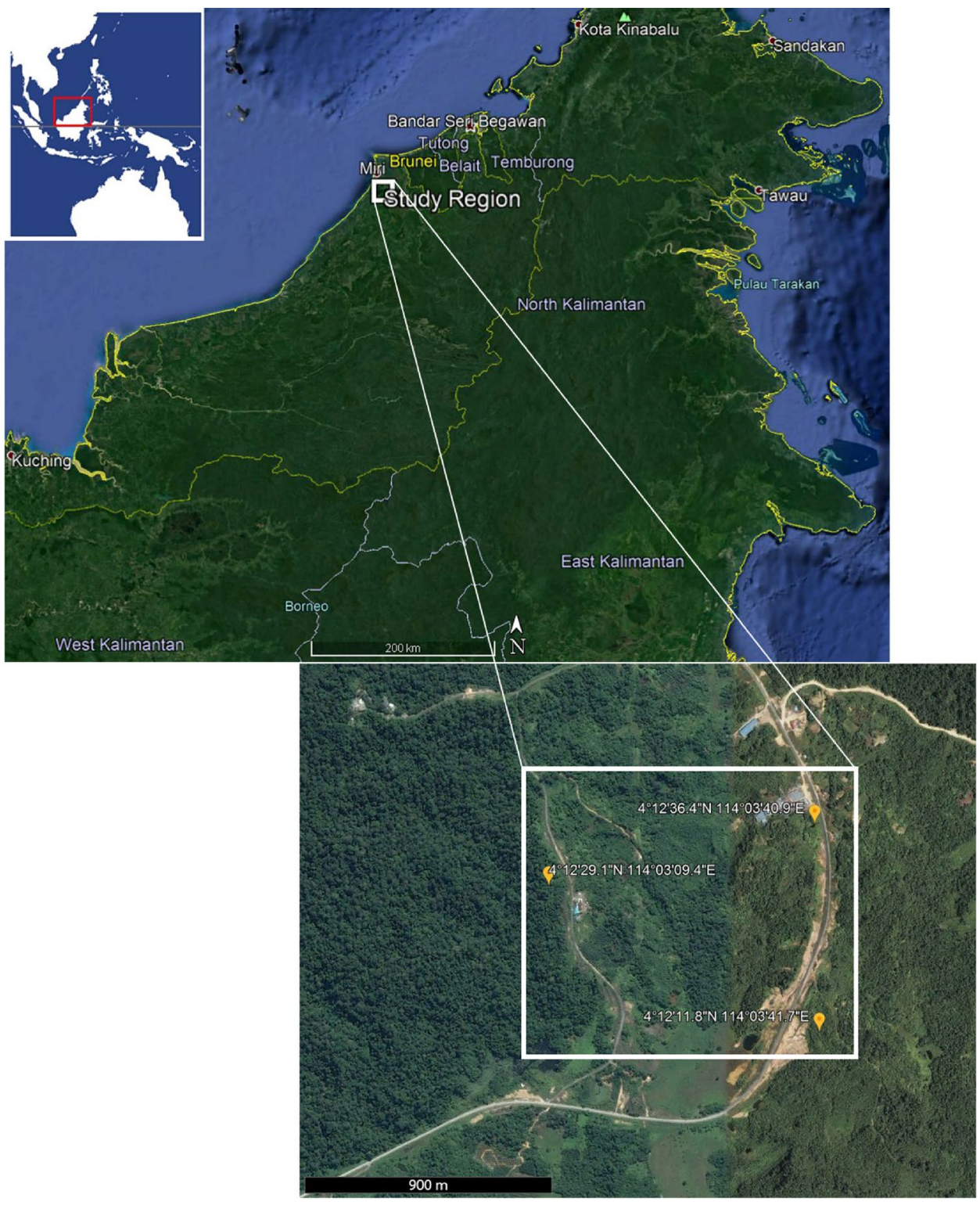

to form in the Early Cenozoic. The Lambir Formation, which Bukit Song is a part of, dates back to Middle to Upper Miocene, approximately between 23 and $11 \mathrm{Ma}$.

Temperature has been considered to have a substantial role in generating petroleum from organic matter enclosed in source rocks (Louis and Tissot 1967; Philippi 1965). The study location is at North West Borneo within Sundaland region/continent. The Sundaland interior has high surface heat flow values, usually greater than $80 \mathrm{~mW} / \mathrm{m}^{2}$ (Hall 2017). By comparison, over the Earth's continental crust, mean heat flow is $65 \mathrm{~mW} / \mathrm{m}^{2}$ (Pollack et al. 1993). Overall, Sundaland is underlain by a thin, hot and weak lithosphere (Hall and Morley 2004) unlike a strong cratonic one. Various climatic changes, ocean upwelling and changing patterns of distribution of living organisms were common place during the Palaeozoic and Mesozoic in South East Asia because of changes in continent-ocean configurations. There are complex interrelationships between plate movements, emergence of land and subsidence, ocean circulation and climate, all of which have influenced the distributions of faunas and floras. Hydrocarbon generation potential hinges on tectonic history of the region as well as factors that control the formation, composition and preservation of organic matter, such as various biogeochemical cycles and time.

This study focused on the integration of geochemical parameters, such as organic geochemical fossils (biomarkers), analysis of organic richness, organic matter composition and thermal maturity, of sedimentary rocks to interpret depositional environment conditions and to estimate the potential for petroleum generation of Bukit Song, as part of the Lambir Formation, which have not been previously investigated. Coaly formations exist in various 


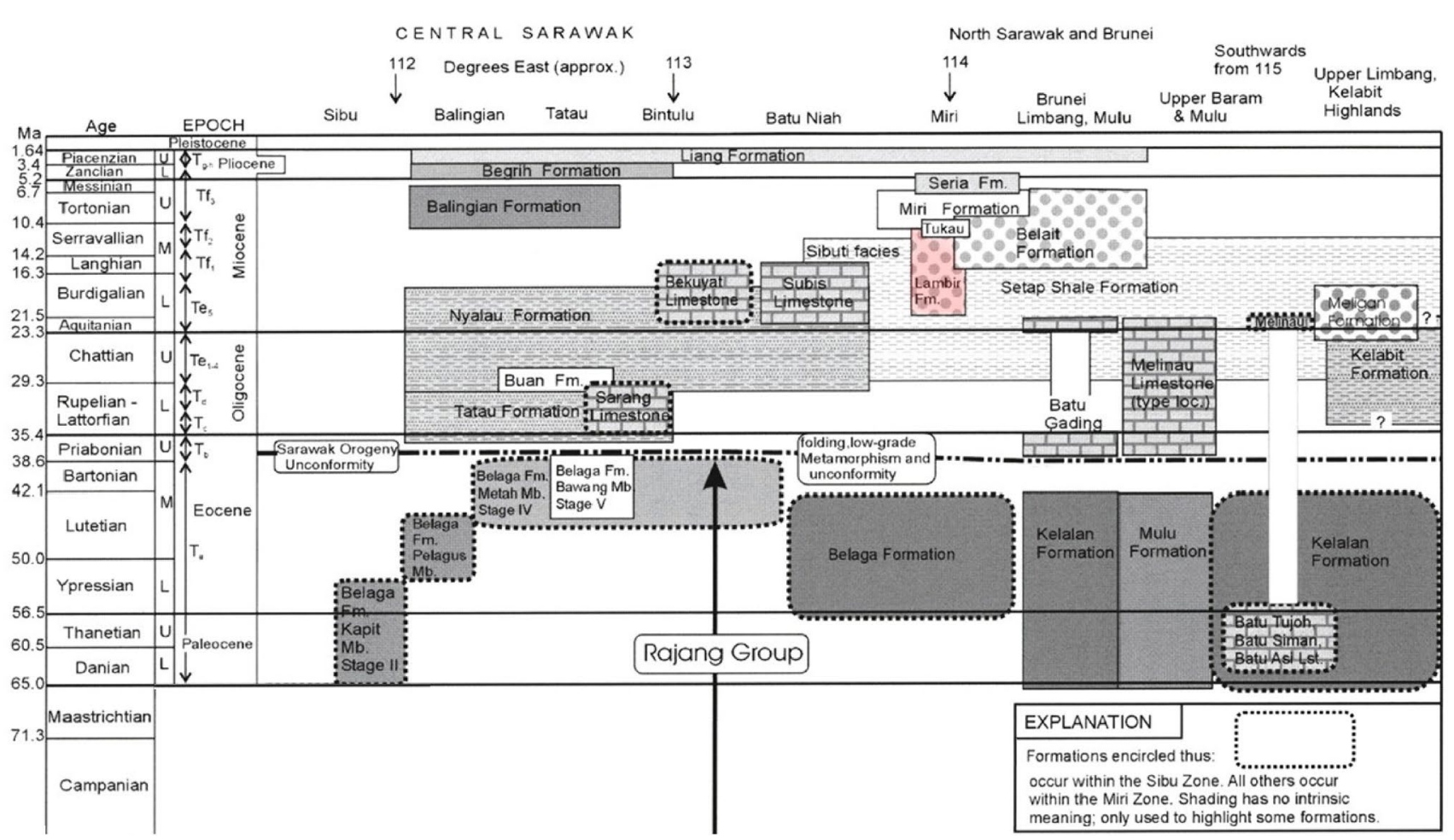

Fig. 2 Chrono-stratigraphic table of the major formations of the Sibu and Miri zones. Setap Shale forms the base of Lambir Formation (after Hutchison 2005)

heterogeneities of the area, which may have hydrocarbon potential. The practical implications of this paper relate to a better hydrocarbon source potential evaluation of the region.

The overall result of this study is in agreement with two studies done within the vicinity of Bukit Song, although not Bukit Song itself. A study done by Togunwa and Wan Hasiah (2017) in Sarawak on several outcrop samples of Lambir, Miri and Tukau formations investigated mudstone samples to be organic rich with a TOC content of more than $1.0 \mathrm{wt} . \%$. Their analyses indicated that there is no significant variation in the source input, depositional conditions and thermal maturity between these formations. They concluded that the sediments are not mature for hydrocarbon generation, supported by vitrinite reflectance values of less than $0.6 \% R_{\mathrm{o}}$. Additionally, Ying (2010) reported immature-early mature samples for both the Lambir Formation and the Miri Formation. Based on $\mathrm{Pr} / n-\mathrm{C}_{17}$ versus $\mathrm{Ph} / n-\mathrm{C}_{18}$, the author reported the Lambir samples (a total of five samples) to be of oxidizing environment of deposition with no contribution from marine sources. The author reported the lack of significant difference in terms of a distinct environment of depositional condition regarding the Miri Formation. Bukit Song, as part of the Lambir Formation, remains to be investigated as regards geochemical parameters that can aid in understanding the petroleum potential of this area.

\section{Materials and methods}

\section{Materials}

A total of 13 outcrop samples (Fig. 3) from the east, southeast and west of Bukit Song were obtained (Table 1). Sampling was limited to the well-preserved exposures; the top surface layers of the outcrops where the samples had been collected from were disregarded from collection in order to avoid weathered and contaminated (by soil and vegetation) prone sections. The samples were put into cartons and ziplock bags (for fragile samples), labelled and brought into the laboratory. Lithofacies' description is provided in Table 2. Figure 4 illustrates the locations of outcrop samples collected in this study.

\section{Methods}

Laboratory techniques performed in this study are X-ray diffraction; petrographic study-including thin sections and maceral analysis; bitumen extraction; Rock-Eval and TOC; liquid chromatography; gas chromatography; and pyrolysis gas chromatography.

All glassware and tools used were first thoroughly scrubbed with a brush and washed with hot soapy water. 

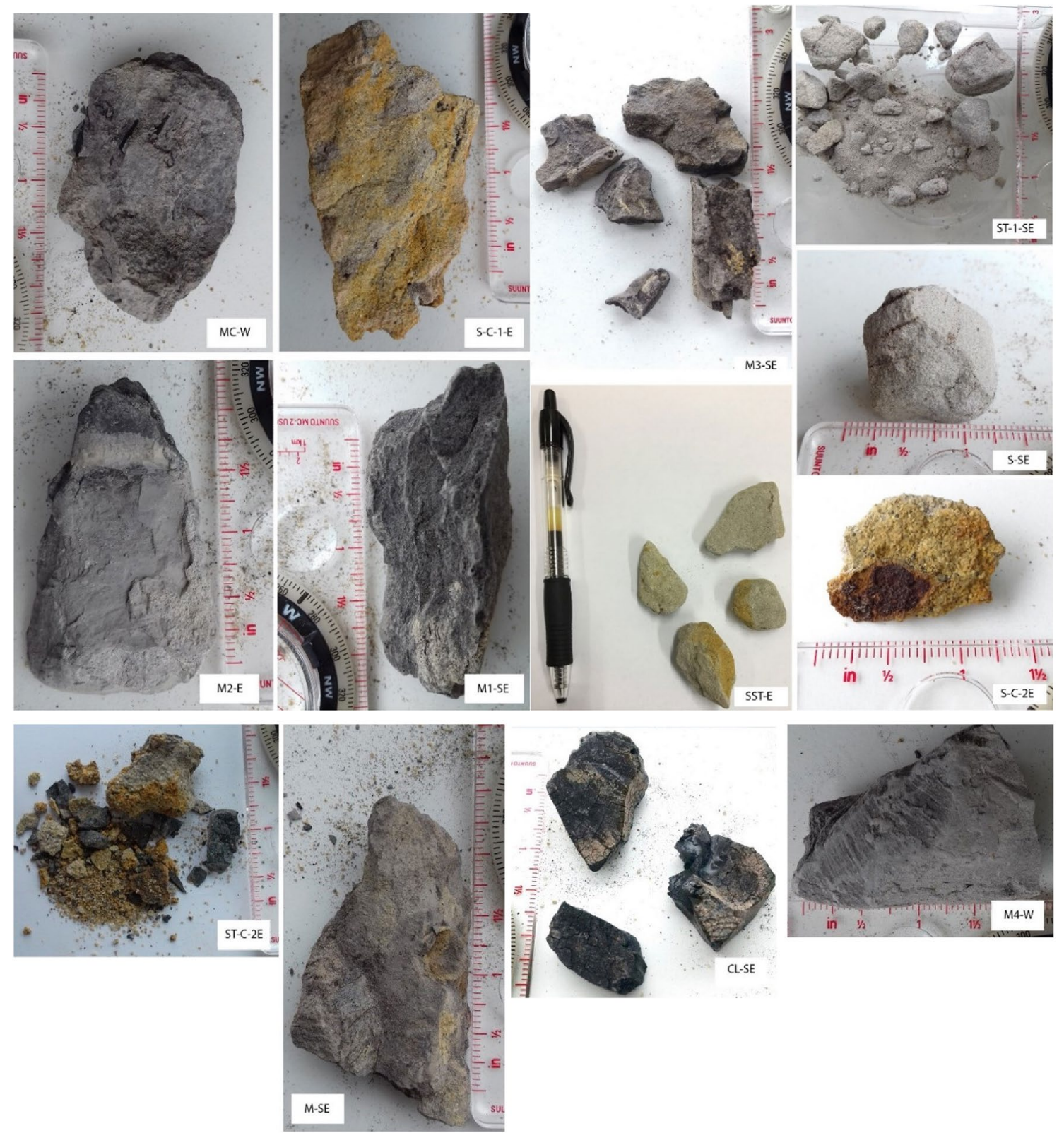

Fig. 3 The samples gathered to be analysed for this study

Table 1 The collecting

locations of the outcrop samples

\begin{tabular}{lllc}
\hline Location & Bukit Song south-east & Bukit Song west & Bukit Song east \\
\hline Coordinates & $4^{\circ} 12^{\prime} 11.18^{\prime \prime} \mathrm{N}$ & $4^{\circ} 12^{\prime} 29.12^{\prime \prime} \mathrm{N}$ & $4^{\circ} 12^{\prime} 36.41^{\prime \prime} \mathrm{N}$ \\
& $114^{\circ} 3^{\prime} 41.65^{\prime \prime} \mathrm{E}$ & $114^{\circ} 3^{\prime} 9.44^{\prime \prime} \mathrm{E}$ & $114^{\circ} 3^{\prime} 40.86^{\prime \prime} \mathrm{E}$ \\
Sample ID & ST-1-SE, M3-SE, M1-SE, S-SE, & MC-W, M4-W & S-C-1E, S-C-2E, \\
& M-SE, CL-SE & & M2-E, ST-C-2E, \\
& & SST-E \\
\hline
\end{tabular}


Table 2 Lithofacies of samples studied

\begin{tabular}{lllll}
\hline Outcrop ID & Sample ID & Lithofacies & Grain size & Other features \\
\hline Bt. Song south-east & ST-1-SE & Sandstone & Very fine & Hardness: very friable \\
$\begin{array}{l}\text { Bt. Song south-east } \\
\text { Bt. Song south-east }\end{array}$ & M3-SE & Shale & Course & With some carbon-rich grains \\
Bt. Song south-east & S-SE & Mudstone & Very fine & Brittle; dark organic rich \\
& & Siltstone & Course silt & Fine dark laminations; sphericity: sub-discoidal; angularity: \\
Bt. Song south-east & M-SE & Mudstone & Silt-grade & Nodules; hardness: hard \\
Bt. Song south-east & CL-SE & Coal & Very fine & Subbituminous coal \\
Bt. Song west & MC-W & Mudstone & Very fine & Hard and brittle; 0.5 to 1 cm long coal fragment laminations \\
Bt. Song west & M4-W & Mudstone & Very fine & Micro-millimetre size black carbonaceous content; grey; soft \\
Bt. Song east & S-C-1-E & Sandstone & Fine & With organic-rich grains; hardness: friable \\
Bt. Song east & S-C-2E & Sandstone & Medium & Well-sorted; sub-discoidal; sub-rounded \\
Bt. Song east & M2-E & Mudstone & Very fine & Hardness is soft; some parts are dark organic-rich \\
Bt. Song east & ST-C-2E & Sandstone & Course & With coaly sections \\
Bt. Song east & SST-E & Sandstone & Fine & Sub-angular; moderately well-sorted \\
\hline
\end{tabular}

Cleaning was followed by rinsing three times in distilled water before being put in a drying oven.

\section{Maceral sample preparation}

The samples that were coaly and muddy were considered for maceral analysis. These samples (CL-SE, ST-C-2E, ST1-SE, MC-W and M4-W) were crushed and mounted in epoxy resins and were ground and polished. As for polishing, first, silicon carbide grinding papers with different levels of coarseness were used with water as lubricant for coaly samples, and ethanol for shaly and muddy samples. Then, a second round of polishing was done using aluminium oxide $3 \mu$ and $1 \mu$ powder. Subsequently, colloidal silica suspension was used for final polishing.

Using incident microscope Leica DM $6000 \mathrm{M}$, the blocks were analysed under white light and UV light. Using standards outlined by Sýkorová et al. (2005), Taylor et al. (1998), and the International Committee for Coal and Organic Petrology (ICCP 1998, 2001), the macerals were described.

\section{Vitrinite reflectance}

Using a Leica DM 6000 M reflected light microscope, vitrinite reflectance was determined on the same six polished block samples used for maceral identification. A calibrated light beam is aimed at a vitrinite particle, and the amount of light reflected from the surface is then measured by a sensor. An optical sapphire glass standard having a reflectance of $0.589 \%$ in oil immersion was used as a means of calibration for vitrinite reflectance measurement. Barker and Pawlewicz (1993) suggest that between 20 and 30 measurements be taken on each sample, if possible, to obtain statistically reliable results. At least 30 measurements from each block were taken for this study. Mean values and standard deviations for each of the populations of vitrinite particles from each sample are reported as percent reflectance in oil immersion.

Out of all the components of coals, vitrinite is considered to be the most suitable for determination of palaeotemperatures (Chilingar et al. 2005). A largely accepted proxy for thermal maturity and hydrocarbon generation can be deduced from vitrinite reflectance measurements at outcrops and in boreholes; however, for this study the vitrinite reflectance is limited to outcrop samples.

There are limitations regarding the use of vitrinite reflectance too. According to Barker (1991) and Wilkins and George (2002), marine-influenced coals can cause vitrinite reflectance suppression. Additionally, there could be incomparable measurements in vitrinite reflectance values when considering dispersed organic matter (Barker 1996; Hackley et al. 2015). There could be a suppression when there is a significant amount of hydrogen-rich materials like liptinite macerals (Raymond and Murchison 1991). A better rank indicator than vitrinite reflectance could be achieved from the elemental analysis of macerals using light-element electron microprobe techniques according to Ward et al. (2006).

\section{X-ray diffraction}

X-ray diffraction pattern provides mineral identification and semi-quantitative analyses based on a comparison of diffraction patterns to a database of known patterns, especially for identification of clays because of their crystalline structure.

Five samples, namely MC-W, M4-W, M3-SE, M2-E, and M1-SE, were analysed using PANalytical Empyrean $\mathrm{X}$-ray powder diffraction (XRD) spectrometry equipped with a 4-kW Rh-anode X-ray tube. 

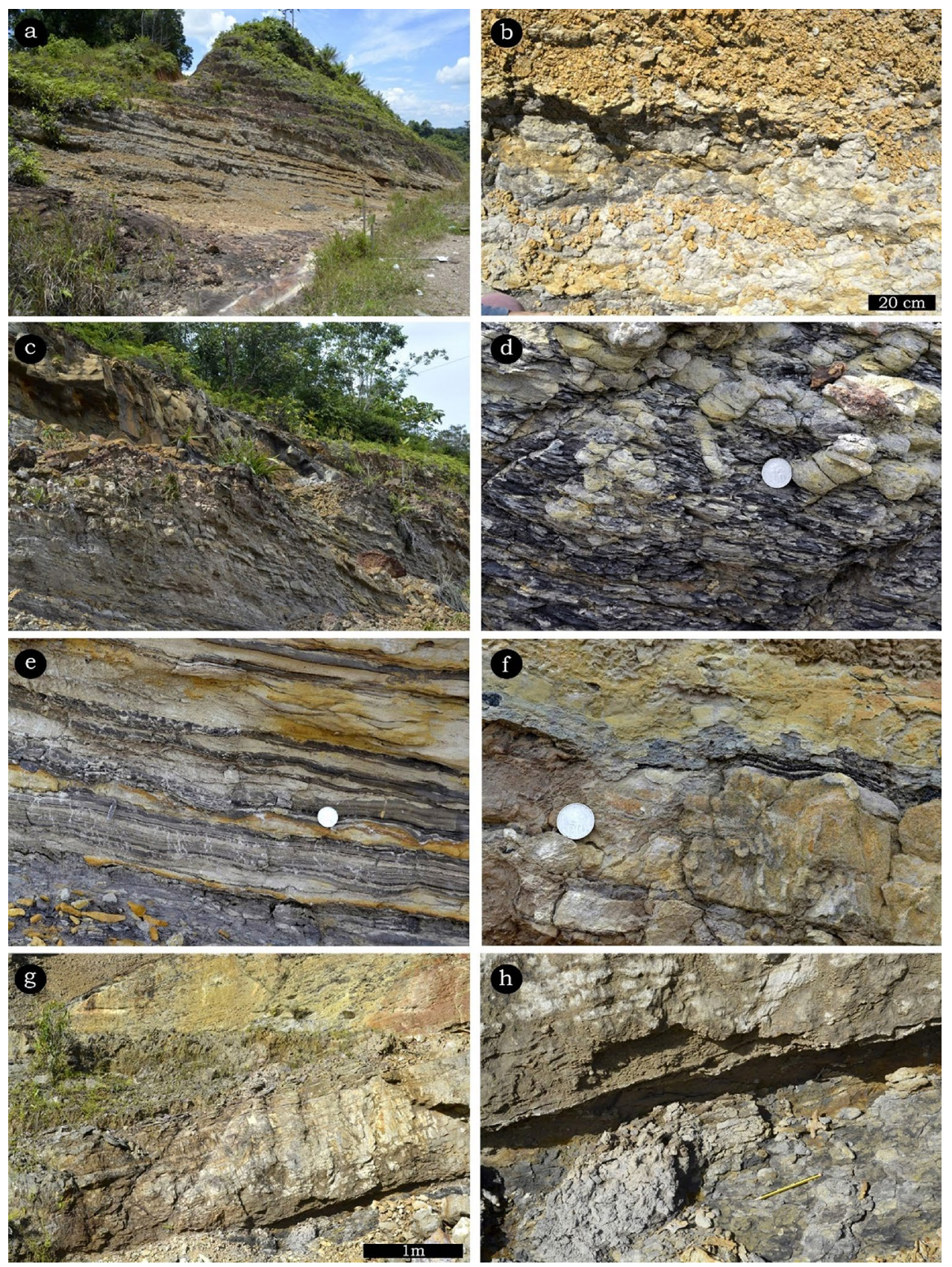

The samples were first crushed into rock chips and were milled — each sample for a round of $10 \mathrm{~s}$ - to a homogeneous powder in a laboratory disk mill using a tungsten carbide grinding barrel.

A slurry of each sample with distilled water was created. The samples were centrifuged for about $10 \mathrm{~min}$. Having allocated sufficient time for particles to settle, each sample was subsequently smeared into glass slide sample holders. Then, the samples were kept in open air to dry out on the glass slides overnight.

Next, the samples were placed into the XRD apparatus and the samples were scanned from 2 to 30 degrees 2 theta to produce the spectrum. The same $2-\theta$ degree is used in the subsequent stages described below.

For the second round, ethylene glycol vapour treatment was preferred over the ethylene glycol rapid method as there are more advantages to the former method, namely less disturbance of the sample and less amorphous scattering of $\mathrm{X}$-rays by excess liquid than in the case of the rapid method. Ethylene glycol treatment was commenced, and the samples were heated to $80{ }^{\circ} \mathrm{C}$ in an oven and kept overnight. As soon as the samples were taken out of the oven the next day, they were placed in the XRD sample holder and the analysis began. Ethylene glycol was used as an auxiliary treatment 
४Fig. 4 a. Bukit Song east. Thin-to-medium parallel stratified sandstone (sample S-C-1-E) interbedded with mudrock. b. Bukit Song east. Sandstone with fine-grained mudstone (sample M2-E). c. Bukit Song south-east. Very thin to very thick coarsening upward (negative grading) beddings of mudstone (sample M1-SE), and shale laminations, as well as sandstone beds, indicating shifts in environmental conditions characterized by regression (a seaward movement of a shoreline) - such as delta cycles. In the case of a delta, coarsergrained deltaic sediments are deposited on top of finer-grained prodelta muds, which results in a coarsening upward vertical succession of facies. It is the regression-seaward migration of the deltaic environment - that brings deltaic sediments on top of prodelta muds to construct the coarsening upward vertical succession. d. Bukit Song south-east. Platy laminated shale (sample M3-SE) with bioturbation, suggestive of shallow-marine contribution. e. Bukit Song south-east. Heterolithic bedding of siltstone/fine sandstone laminae (sample S-SE), lenticular and wavy laminae and very thin beds within mudstones (sample M-SE); symmetrical to asymmetrical ripples of lenticular to flaser lamination in parts, and few siltstone laminae discontinuous; most laminae have sharp contacts; probably low energy shallow-marine tidal setting with some fluctuations of flow strengths due to flaser beds. Organic-rich alternate laminations can be seen from S-SE, showing quiet sedimentation, where the minerals are either carbonates or transported as pre-existing rocks, including clay minerals and silt. The lamination is suggestive of recurrent or periodic events, proving the absence of benthic organisms, suggestive of a restricted environment where the decomposition of part of the organic matter uses up $\mathrm{O}_{2}$ to produce $\mathrm{CO}_{2}$ enhancing organic matter preservation. Samples from south-east are mainly plotted within the oxic region based on phytane $/ n-\mathrm{C}_{18}$ vs. pristane $/ n-\mathrm{C}_{17}$ plot. f. Bukit Song south-east. Thickly bedded sandstone with thin mudrock laminae, as well as very thin sub-parallel wavy laminations of with coal lenses (sample CL-SE). The orange to reddish surface colour probably is an indication of high oxic environment. g. Bukit Song west. A very tick sandstone bed with shaly organic-rich section at the bottom. h. Carbonaceous mudrock (sample M4-W) at Bukit Song west

to expand swelling clays. Whether or not a mineral expands and the amount of expansion can provide crucial supplementary information aiding clay-mineral identification once the XRD spectrum is ready. The most common swelling or expandable clays include smectites (e.g., montmorillonite, saponite, nontronite and beidellite), some mixed-layer clays, and vermiculite.

Next, the samples were placed into a furnace and heat was slowly increased to $350^{\circ} \mathrm{C}$. For around $30 \mathrm{~min}$, the samples were heated at constant $350{ }^{\circ} \mathrm{C}$. Having allocated enough time for the samples to cool down, the samples were run on the X-ray diffractometer. Finally, the furnace was heated to $550{ }^{\circ} \mathrm{C}$. Again, the samples were kept at this temperature for $30 \mathrm{~min}$. Sufficient time was allowed for the samples to cool down before running the samples on the XRD.

\section{Bitumen extraction (Solid-liquid extraction)}

Soluble organic materials extracted from rocks are known as bitumen (Peters et al. 2005) and can be removed from finely ground rocks by solvent extraction in a system called a Soxhlet extractor.
First, a set of agate mortar and pestle was used to make the samples to a powder. The agate mortar and pestle were first washed with warm soapy water, rinsed with distilled water three times and dried in oven before use. Each preweighed sample was then placed inside the pre-weighed thimble and capped using cotton to be placed inside the Soxhlet column.

In this method, azeotropes of dichloromethane $\left(\mathrm{CH}_{2} \mathrm{Cl}_{2}\right)$ and methanol $\left(\mathrm{CH}_{3} \mathrm{OH}\right)$ with a ratio of 93:7 were used as solvents. Additionally, pieces of copper turnings were added to the flasks acting as sulphur absorbent. Anti-bumping granules in the form of fused alumina $\left(\mathrm{Al}_{2} \mathrm{O}_{3}\right)$ were also added to decrease the volatility of the boiling liquid and prevent flash boiling.

Heating the percolator (boiler) which circulates the solvent began and the operation ran for $72 \mathrm{~h}$. By heating, the vapour rises through the extraction column to the area where the condenser is cooled, condensing the vapours that fall back onto the cartridge, and hence, the active ingredient of the solid (bitumen) was extracted.

Subsequently, solvent was removed by means of a rotary evaporator (Butchi), yielding the extracted bitumen. Removal of the solvent by evaporation leaves a heavy hydrocarbon extract containing compounds with 15 or more carbon atoms and identified as the "C15 + extract." In the rotary evaporation method, the flask containing the sample was partially immersed in a water bath of $46^{\circ} \mathrm{C}$, maintaining the rotation for about $8 \mathrm{~min}$. Afterward, the mixture in the flask — now with reduced solvents-was transferred using a Pasteur pipette to an open test tube and left to dry off completely. Having recorded the weights of the test tubes first, subsequently, the weight of bitumen was measured by subtracting it from the weight of the test tubes. The process was repeated for all samples.

\section{Column chromatography (liquid chromatography)}

Vertical columns used were first thoroughly washed and dried in the oven. The extracted organic matter (EOM) mixture was poured onto a vertical column packed with a slurry of silica gel pre-mixed with solvent, and then, pure solvent was continuously added. The components in the mixture were fractionated down the column. Separation occurs because the various components move at different rates depending on their interaction with the packing - the greater the interaction the more time they spend adsorbed, and the slower they move. This process separates Soxhlet extracts, commonly referred to as EOM, into organic compounds, namely aliphatic and aromatic compounds, as well as heteroatoms: NSO (nitrogen, sulphur and oxygen) fractions.

Distinct solvents were added to the vertical column for the extraction of aliphatic, aromatic and NSO fractions. Methanol is used for NSO extraction, petroleum ether is

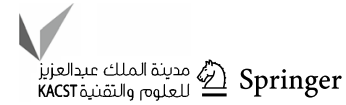


used for aliphatic extraction and dichloromethane (DCM) is used for extraction of aromatic compound.

\section{Rock-Eval pyrolysis and TOC}

Pyrolysis is used to measure richness and maturity of potential source rocks. In a pyrolysis analysis, the organic content is pyrolysed in an inert gas and then combusted. Large hydrocarbon molecules are broken into smaller molecules; the amounts of hydrocarbons and carbon dioxide released are measured. Rock-Eval is a rapid screening tool in evaluating the quantity, quality and thermal maturity of rock samples. It can help determine the type of kerogen. Determination of soluble (bitumen) and insoluble (kerogen) portions of the dispersed organic matter is necessary for its complete characterization. Hence, the use of Rock-Eval pyrolysis contributes greatly to the bitumen extraction analysis.

Total organic carbon (TOC) is an important parameter to determine reservoir potential of any source rock play. Carbon is present in all organic components of a rock, namely kerogen, bitumen and hydrocarbons. Specifically, properties like maturation of the organic matter and hydrocarbon type influence TOC. TOC is a measure of the quantity of the organic carbon or source richness in rock sample. It is determined by oxidizing the pyrolysis residue in a separate oven at $600{ }^{\circ} \mathrm{C}$. The organics are converted to carbon dioxide, which can then be measured. This quantity gives a measure of the organic carbon content of the rock, not the organic matter content. The TOC analysis measures both the total carbon present and the inorganic carbon. The so-called inorganic carbon represents the content of dissolved $\mathrm{CO}_{2}$ and carbonic acid salts. Subtracting the inorganic carbon from the total carbon yields TOC.

For Rock-Eval and TOC analysis, the samples were crushed into a powder using a set of agate mortar and pestle, packed and labelled, then sent to Core Laboratories.

The first peak $\left(\mathrm{S}_{1}\right)$ of the curve corresponds to the free and adsorbed hydrocarbons evaporated at a moderate heating to $200-250{ }^{\circ} \mathrm{C}$. The second peak $\left(\mathrm{S}_{2}\right)$ reflects hydrocarbons and other similar components generated at a higher temperature due to pyrolysis of the insoluble portion of the organic matter (kerogen). The third peak pyrolysate $\mathrm{S}_{3}$ reflects $\mathrm{CO}_{2}$ and $\mathrm{H}_{2} \mathrm{O}$ produced during pyrolysis of kerogen. $T_{\max }$ is a thermal maturity parameter of Rock-Eval pyrolysis that is based on the temperature at which the maximum amount of pyrolysate $\mathrm{S}_{2}$ is generated from the kerogen in a rock sample. The commencement and the end of the oil-generative window roughly correspond to $T_{\max }$ of $435{ }^{\circ} \mathrm{C}$ and $470{ }^{\circ} \mathrm{C}$, respectively (Peters 1986).

\section{Results}

\section{Maceral and mineral analyses}

Petrographic analysis in incident light microscopy encompasses the identification of organic components, its quantification, physical/optical characteristics and uncovering of rank/maturity. Furthermore, maceral identification aids identifying the possible types of kerogens and their potential in petroleum generation. Maceral compositions also reveal the depositional environment conditions.

Owing to the existence of organic particles which are generally large, maceral groups can be identified using incident light microscopy on polished coal rock blocks.

Microphotograph A1 (Fig. 5) of sample CL-SE shows semifusinite (labelled as Sfs) whose preserved cell cavities are filled with exsudatinite that migrated there (A2). Semifusinite originates from the cellular tissues making up the soft parts and xylem tissues of stems, herbaceous plants and leaves, which are composed of cellulose and lignin. It is formed in the peat stage by weak humification, dehydration and redox processes. Depending upon its degree of chemical transformation, semifusinite belongs to kerogen type III-IV (ICCP 2001).

Cutinite (labelled as Cuti) maceral is shown in Fig. 6 B1 and B2 (under UV light), which is the part of the liptinite maceral group that contains relatively high percentages of aliphatic substances (Guo and Bustin 1998). Cutinite is formed from cuticles of leaves and stems.

Although hydrogen-rich liptinite is considered an important source for liquid petroleum, the beginning of hydrocarbon generation from liptinites is different: it varies based on the type of liptinite macerals and particular thermal maturities. Suberinite, bituminite and terpene resinite, for instance, often generate petroleum at a lower rank (at about $0.4 \% R_{r}$ ), whereas cutinite and alginite exhibit their peak generation at about 0.7-0.8 1\% $R_{r}$ (Khorasani and Murchison 1988; Wan Hasiah 2003). Cutinite is also rarely a significant component in most marine facies as far as environmental interpretation is concerned. The analysed coal consists mainly of detritus from higher plants as evident from high percentage of vitrinite maceral within the sample. It can be said the sediments as part of CL-SE sample received substantial land plant input in this transition environment that were probably influenced by some marine environment (e.g., marine transgression) as observed by moderate liptinite maceral. The relatively high pyrite and high sulphur content could hint at a possibility of marine influence. Nonetheless, high sulphur content in the coal sample may be due to pyrite predominantly, rather than from a highly marine influence, because of concurrently high vitrinite content in the sample. The mineral constituents in coal may represent transformed accumulations of 
Fig. 5 Photomicrographs of sample CL-SE
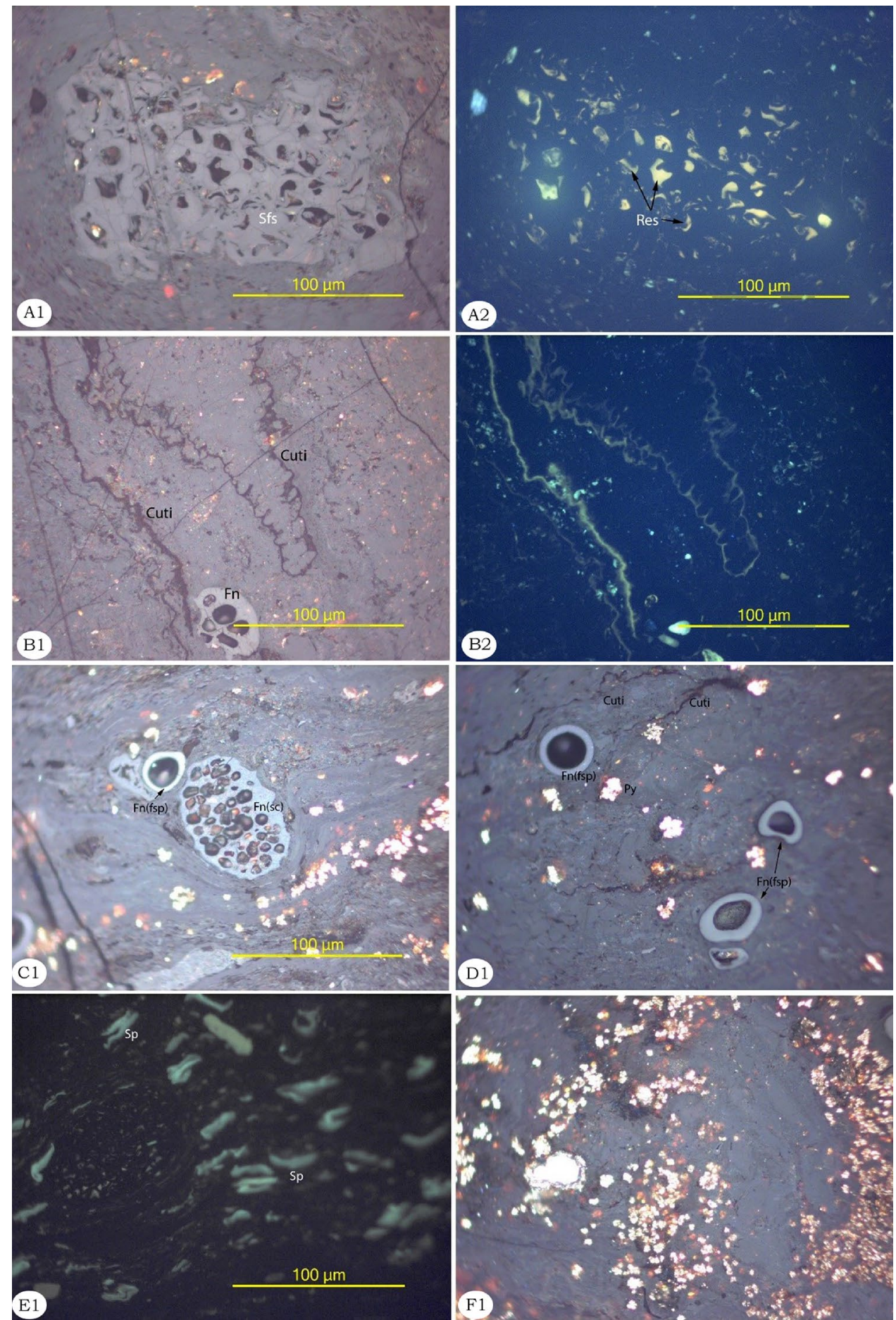

biologically derived components, like phytoliths and skeletal fragments (Raymond and Andrejeko 1983), or they may be of detrital origin, introduced as epiclastic or pyroclastic particles into the peat bed (Davis et al. 1984).

C1 and D1 microphotographs from same sample (Fig. 5) show funginite of fungal spores Fn (fsp) and sclerotia Fn (sc) from the inertinite maceral subgroup occurring in association with vitrinite maceral. Funginite maceral consists of mainly high reflecting single- or multi-celled fungal spores, sclerotia, hyphae and mycelia, and other fungal remains. The occurrence of funginite could be an indication of fossil or recent weathering of peats (ICCP 2001). Figure 5 E1 shows sporinite maceral that originates from the outer cell walls of spores and pollens. A high number of pyrite framboids are seen, an evidence of reducing environment 


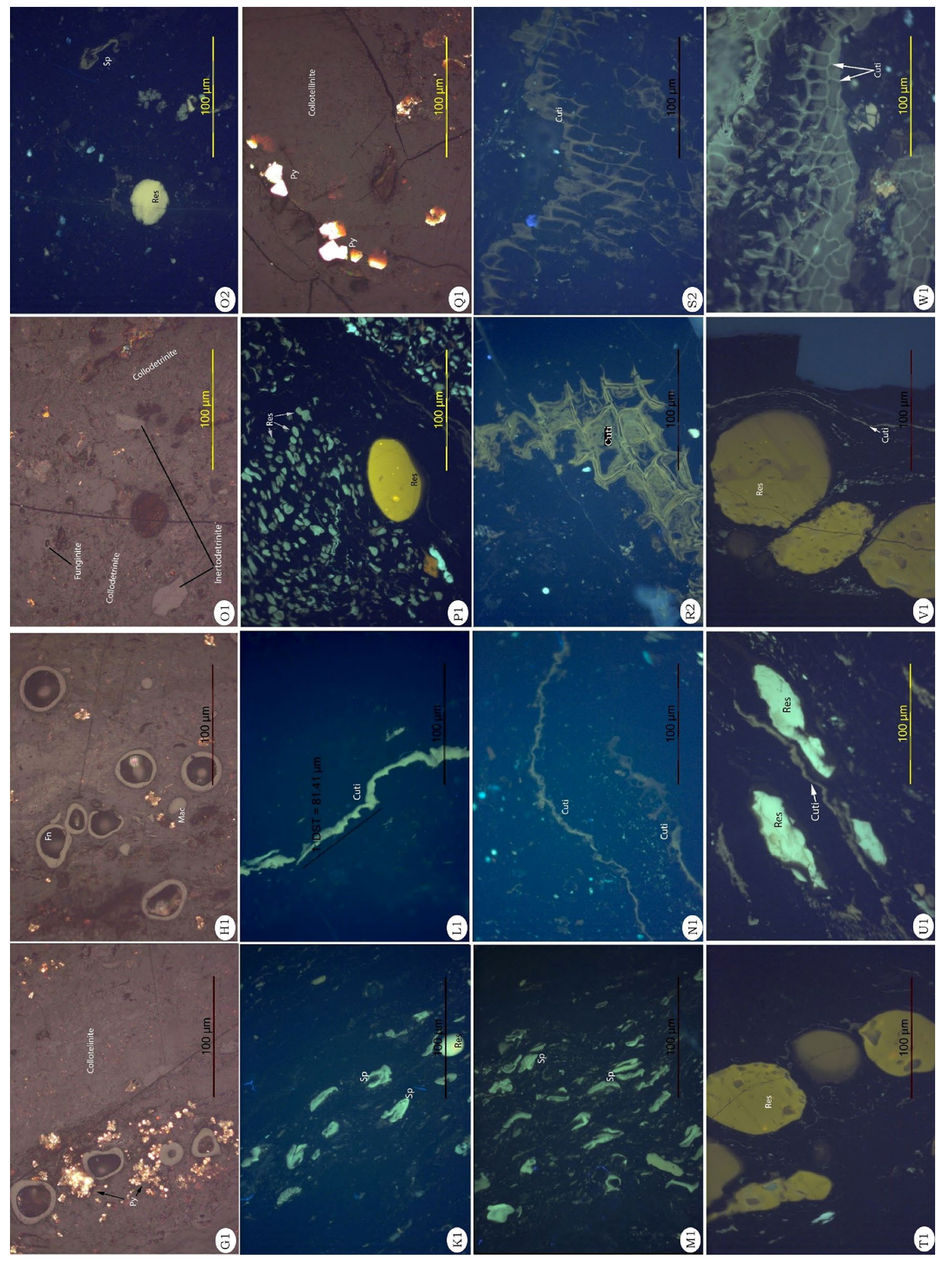

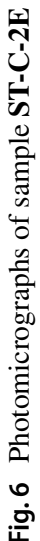


Overall, vitrinite is the dominant maceral signifying more gas-proneness, followed by liptinite and inertinite. Funginite, semifusinite and inertodetrinite were observed from sample CL-SE.

Photomicrograph of sample ST-C-2E (Fig. 6) shows abundant inertinite macerals: funginite, macrinite, and semifusinite. Common occurrence of framboidal pyrite can be easily seen within vitrinite. Suberinite and cutinite are observable as well. At white light, cutinite is seen (photo R2). Resinite and cutinite are considered to play a significant role in the early generation ( $\mathrm{VR}=0.45 \%$ ) of oil from coal.

Sporinite and cutinite are shown in Fig. $6 \mathrm{M} 1$ and N1. Sporinite and liptodetrinite (oxidized and biodegraded fragments of other liptinites) have a lower liquid hydrocarbon potential than do the morphologically intact liptinites and are thermally less likely to break down, requiring greater thermal maturities $(\mathrm{VR}=0.7 \%)$ to release their hydrocarbons (Powell and Boreham 1991).

Resinite macerals with different shapes and florescence colours are seen (Fig. 6), possibly indicating different origins. Cutinite can also be observed showing relatively wellpreserved cell structure.

Overall, ST-C-2E shows higher abundance of liptinite macerals, in particular higher suberinite and resinite content compared to CL-SE. It can be inferred from sample STC-2E that it has higher hydrogen and oil-prone propensity compared to CL-SE, although still it is immature, belonging to the kerogen type III. Liptinite abundance can provide information on $\mathrm{H} / \mathrm{C}$ and percentage of liptinite (extinite) in thermally immature coals.

Both vitrinite staining and bitumen staining exist in sample ST-1-SE. The lower degree of vitrinite reflectance of the sample $(0.52 \%)$ could be due to the coexistence of varying degrees of the bitumen staining. Also seen is brownish bitumen staining associated with vitrinite.

Photomicrographs of sample MC-W (Fig. 7 A12 and A13) show vitrinite phytoclasts associated with oil haze and cutinite. Type II amorphous organic matter (AOM) associated with non-florescence type III kerogen was also observed. In general, the more fluorescing amorphous kerogen is present, the more oil-prone the rock is. However, not all amorphous kerogens can generate oil; from the modified van Krevelen diagram the sample is part of kerogen type IV. Hydrogen-rich, oil-prone amorphous is fluorescent. 'AOM' is usually the dominant kerogen part in upwelling influenced dysoxic sediment facies (Davey and Rogers 1975). Also, according to Tissot and Pelet (1981), an abundance of 'AOM' in modern marine sediments appears to be especially diagnostic of dysoxic to anoxic facies. Dysoxic conditions also are associated with sample MC-W based on the plot of phytane $/ n-\mathrm{C}_{18}$ versus pristane $/ n-\mathrm{C}_{17}$.

Significant abundance of euhedral pyrite is observable from sample ST-C-2E and M4-W. The occurrence of framboidal pyrite is evident in other samples. Framboids and euhedral sedimentary pyrite can each be a result of specific pathways of pyrite formation. Direct precipitation from solution may result in euhedral pyrite, whereas framboids form indirectly via iron monosulphides, or when there is stability in the internal geometric patterns and/or the surrounding material has sufficient plasticity to be displaced Sawlowicz (1993).

\section{Vitrinite reflectance}

Vitrinite reflectance is a measure of the thermal maturity of organic matter. The cumulative time and temperature history or thermal stress of sediments is represented by vitrinite reflectance. Interpretation of vitrinite reflectance is helpful in identifying which source rocks are potential contributors to a petroleum system. Vitrinite reflectance, amongst other parameters, can be used in basin modelling to substantiate the modelled thermal history. Direct geochemical indicators and basin modelling are needed to confirm the issues of generation and expulsion (Dembicki 2009).

Vitrinite reflectance mean value histograms are provided in Appendix B. Vitrinite reflectance mean values with standard deviation errors are presented in Table 8.

The analysed samples are presently still immature for any hydrocarbon generation based on vitrinite reflectance measurements $(0.35-0.58 \% \mathrm{Ro})$, which correspond to less than $435{ }^{\circ} \mathrm{C}$ of $T_{\max }$. The main phase of oil generation from type I and II kerogens, which account for the greater proportion of the world's petroleum reserves, is considered to correspond to the vitrinite reflectance range $0.55-1.30 \%\left(T \max =435-470{ }^{\circ} \mathrm{C}\right)$. Peak generation occurs at $\mathrm{VR}=0.80-0.90 \%$. Hence, there is no promising potential for petroleum generation based on the vitrinite reflectance values.

\section{XRD Spectrometry}

The results of XRD analysis are presented in Fig. 8.

Based on the analysis of the X-ray patterns, illite $(10 \AA$, $5.03 \AA, 3.35 \AA$ ) and kaolinite $(7.13 \AA$ and $3.58 \AA$ ) were identified as the major clay minerals in all samples-both being non-swelling types. Also, all samples showed a greater amount of illite over kaolinite. Existence of kaolinite and illite in addition to the thin section analysis signifies limited porosity.

As can be seen, heating samples to $550{ }^{\circ} \mathrm{C}$ have resulted in $7 \AA$ peak of kaolinite disappearing because the structure dehydroxylates.

Large coherent scattering domains of quartz are due to its well-crystalline structure; hence, quartz peaks appear sharper. 
Fig. 7 Photomicrographs of samples ST-1-SE, M4-W and MC-W. Photomicrographs of sample M4-W (Fig. 12 A10 and A11) show pyrite associated with stained vitrinite. Vitrinite phytoclasts can be seen as elongated lenses. Photomicrographs $\mathrm{X} 1$ and $\mathrm{X} 2$ of sample ST-1-SE show bitumen staining in amorphous clay mineral associated with vitrinite phytoclasts. The staining in this sample could either be in situ or of migratory origin. It is also possible that in $\mathrm{Y} 1$, the brown colour along the edges of vitrinite could be an artefact of the thickness of the grains and the way the light reflects. Bitumen staining is also seen in A11

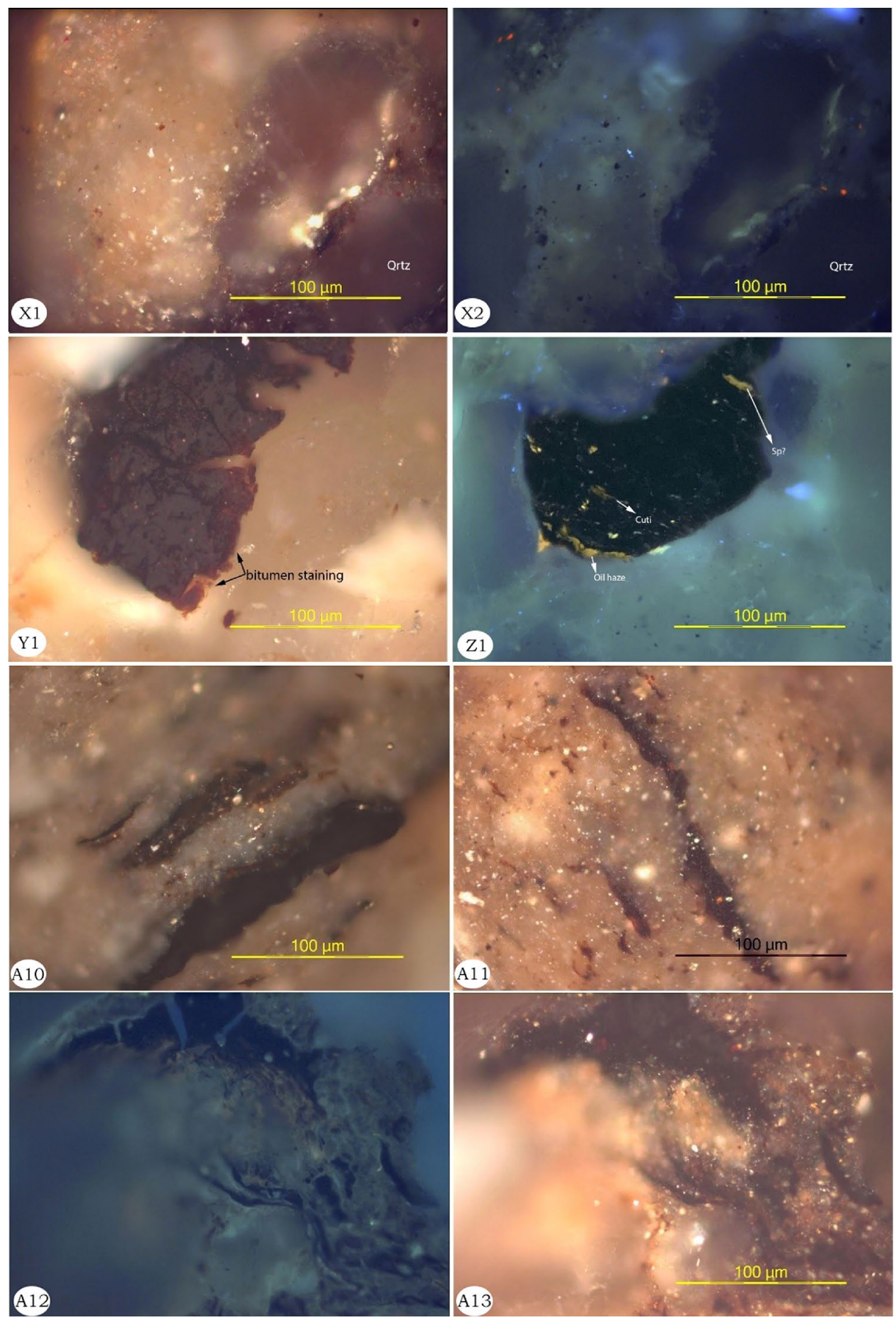

Clay minerals can be a result of weathering and erosion, but not affected due to changes in the peat environment. The origin of the greatest amount of clay material is in the process of weathering, either subaerial or subaquatic. A humid climate, such as that of Malaysia, will favour the formation of kaolinite, for instance.

Based on the results of this study, neither smectite, nor tobelite was detected. Generally, as illite increases, diagenetic stages advance. The presence of illite-smectite-tobelite is an independent evidence of oil generation, whilst the absence of tobelite layers indicates that the rock has not been heated adequately to generate large amounts of oil (Drits et al. 2002).

Kaolinite as the coarsest grained clay mineral is deposited in the most proximal parts of shorefaces and deltas. On the other hand, illite and smectite will be transported 

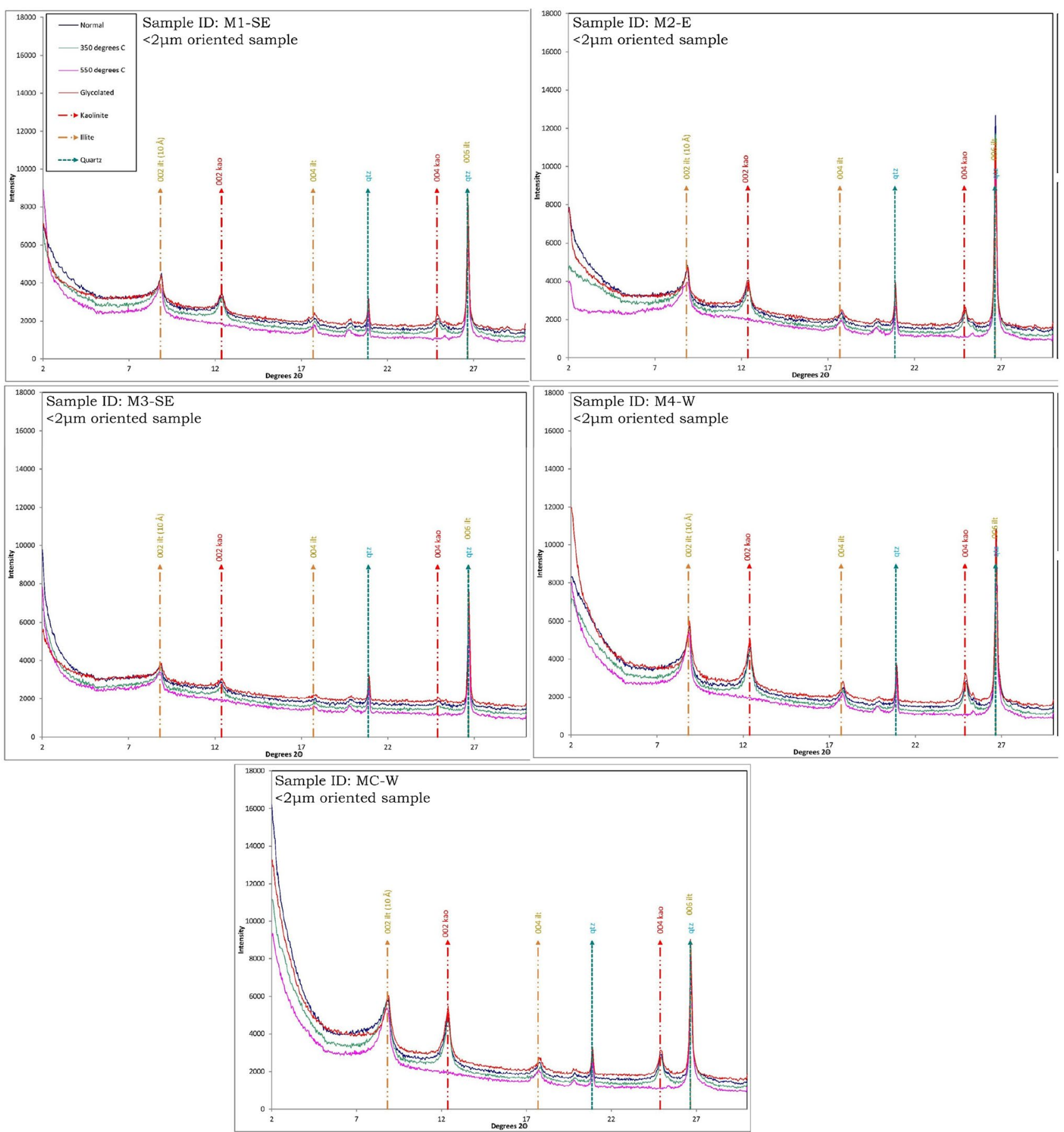

Fig. 8 XRD of samples M1-SE, M2-E, M3-SE, M4-W and MC-W

further out into the more distal parts, forming the base of sedimentation and grading upwards into more kaolinite-rich sediments (Bjørlykke 2015). A greater contribution of illite in the sample analysed could suggest a distal environment.

\section{Bitumen extraction (Solid-liquid extraction)}

The results of bitumen extraction analysis are presented in Table 3.

Sample CL-SE yielded the highest amount of bitumen, followed by M4-W, M1-SE, M3-SE, and ST-C-2E, all having excellent petroleum potential (above $>4000 \mathrm{ppm}$ 
Table 3 The results of bitumen extraction

\begin{tabular}{lllc}
\hline Sample ID & Sample weight $(\mathrm{g})$ & EOM $(\mathrm{g})$ & EOM $(\mathrm{PPM})$ \\
\hline ST-1-SE & 15.629 & 0.006 & 383.90 \\
M3-SE & 14.39 & 0.067 & 4656.01 \\
M1-SE & 16.164 & 0.0868 & 5369.95 \\
CL-SE & 3.0044 & 0.108 & 36013.85 \\
MC-W & 14.602 & 0.0196 & 1342.28 \\
M4-W & 15.455 & 0.1201 & 7770.94 \\
M2-E & 14.524 & 0.035 & 2409.80 \\
ST-C-2E & 14.775 & 0.0648 & 4385.78 \\
\hline
\end{tabular}

extracted bitumen or C15 + hydrocarbons). Sample M2-E is considered as having very good petroleum potential with an EOM of about 2400 ppm. Sample MC-W has good petroleum potential whose EOM is within 1000-2000 ppm range. ST-1-SE has poor petroleum potential with under just about $400 \mathrm{ppm}$.

\section{Column chromatography (liquid chromatography)}

The results of liquid chromatography analysis are depicted in Table 4.

The analysed samples do not show particularly similar molecular weights as observed from the comparison of aromatic hydrocarbons and NSO. According to Peters et al. (2005) expulsion/migration may affect the distribution of such compounds; for instance, migrated oils are usually enriched in aromatic hydrocarbons, however, depleted in NSO.

M4-W yielded EOM at a range of 'good' petroleum potential; it has yielded the highest amounts of combined aliphatic and aromatic compared to other samples. It is enriched in aliphatic compounds, unlike other samples which are richer in aromatic compounds. Followed by M4W in terms of hydrocarbon, it is CL-SE that showed the highest petroleum potential. It also has a marginally higher
NSO compounds than all the other samples, which is not unusual given the sample is a coal. M3-SE shows the highest ratio of aromatic to aliphatic compounds with a ratio of $4: 1$, hence having more potential of being considered as higher ranked, kerogen type II, mixed, or gas generative.

Based on the literature type-I, kerogen presents many examples of oil shales containing high amounts of long aliphatic chains and little polyaromatic material based on infrared spectrophotometry as well as analysis of extracted bitumen. Liptinite macerals contain mostly aliphatic compounds and have high potential for hydrocarbon generation. Type-II kerogen contains more aromatic and naphthenic materials (Tissot and Welte 1984).

High NSO percentage of all samples except CL-SE can be indicative of low thermal maturity since as oils get more thermally mature, they are more likely to have reduced amounts of NSO compounds. Sample CL-SE is identified as a humic type of coal (being rich in oxygen as a heteroatom). Oxygen is the major heteroatom in humic substances. In contrast, sapropelic coals are formed from fairly fine-grained organic muds in quiet shallow waters that are deficient in dissolved oxygen.

Table 5 Biomarker information based on gas chromatograms

\begin{tabular}{lllll}
\hline Sample ID & Pristane/phytane & Pristane $/ n$ - $_{17}$ & Phytane $/ n-\mathrm{C}_{18}$ & CPI \\
\hline ST-1-SE & 1.13 & 0.47 & 0.16 & 1.1 \\
M3-SE & 2.26 & 3 & 1.05 & 3.08 \\
M1-SE & 4.18 & 7.64 & 1.35 & 2.12 \\
CL-SE & 1.38 & 3.46 & 2.13 & 1.59 \\
MC-W & 1.2 & 0.41 & 0.8 & 2 \\
M4-W & 2.37 & 3.55 & 0.906 & 1.38 \\
M2-E & 1.14 & 0.16 & 0.22 & 0.807 \\
ST-C-2E & 2.93 & 1.21 & 0.45 & 1.12 \\
\hline
\end{tabular}

Table 4 The results of liquid chromatography

\begin{tabular}{llllllllr}
\hline Sample ID & Aliphatic (g) & Aliphatic $\%$ & Aromatic (g) & Aromatic $\%$ & NSO (g) & NSO \% & $\begin{array}{l}\text { HC (ali- } \\
\text { phatic + aro- } \\
\text { matic) (g) }\end{array}$ & $\begin{array}{l}\text { HC (ali- } \\
\text { phatic + aro- } \\
\text { matic) (PPM) }\end{array}$ \\
\hline ST-1-SE & 0.0007 & 10.6 & 0.0014 & 21.2 & 0.0045 & 68.2 & 0.0021 & 134.36 \\
M3-SE & 0.0022 & 3.3 & 0.0089 & 13.3 & 0.0275 & 41.0 & 0.0111 & 771.36 \\
M1-SE & 0.0048 & 5.5 & 0.0086 & 9.9 & 0.0332 & 38.2 & 0.0134 & 829.00 \\
CL-SE & 0.0019 & 1.8 & 0.0038 & 3.5 & 0.0178 & 16.5 & 0.0057 & 1897.21 \\
MC-W & 0.0028 & 14.3 & 0.0041 & 20.9 & 0.0131 & 66.8 & 0.0069 & 472.53 \\
M4-W & 0.0361 & 30.1 & 0.0039 & 3.2 & 0.0787 & 65.5 & 0.04 & 2588.15 \\
M2-E & 0.0018 & 5.1 & 0.0035 & 10.0 & 0.0132 & 37.7 & 0.0053 & 364.91 \\
ST-C-2E & 0.0039 & 6.0 & 0.0095 & 14.7 & 0.0205 & 31.6 & 0.0134 & 906.93 \\
\hline
\end{tabular}




\section{Gas chromatography (GC)}

Aliphatic compounds-which include alkanes and alkenesare hydrocarbons in petroleum, containing saturated and/ or single unsaturated bonds that get removed during liquid chromatography using non-polar solvents.

Based on gas chromatograms, the values of biomarkers pristane/phytane, pristane $/ n-\mathrm{C}_{17}$, as well as phytane $/ n-\mathrm{C}_{18}$ were calculated, as presented in Table 5.

Pristane usually corresponds with oxidizing conditions, whereas phytane is commonly linked with reducing or anoxic conditions (Powell \& McKirdy 1973). Therefore, pristane/phytane ratio is used for interpretation of redox conditions, as shown in Table 6.

The plot of phytane $/ n-\mathrm{C}_{18}$ versus pristane $/ n-\mathrm{C}_{17}$ (Fig. 9) shows no particular locality-based distinction for Bukit Song's three main locations (south-east, west and east). The most common depositional environment is peat coal where four samples (ST-1-SE, ST-C-2E, M4-W and M3-SE) were gathered from. Overall, all samples show higher tendency towards oxic conditions, except samples M2-E and MC$\mathbf{W}$ that indicate deposition under reducing conditions, as well as CL-SE which plots in the mixed/transitional zone. In comparison with the two mentioned samples, CL-SE shows higher $\mathrm{Pr} / \mathrm{Ph}$ value indicating generation from source rocks deposited under higher oxic conditions consistent with phytane $/ n-\mathrm{C}_{18}$ vs. pristane $/ n-\mathrm{C}_{17}$ plot. A higher than $1 \mathrm{Pr} / \mathrm{Ph}$ value is also an indicative of shale source rocks. The existence of marine depositional environment based on M2-E and MC-W is in contrast to Ying's (2010) thesis on Lambir Formation where no marine contribution had been found from her analysed samples.

Based on pristane/phytane and phytane $/ n-\mathrm{C}_{18}$ vs. pristane $/ n-\mathrm{C}_{17}$ values, samples M1-SE, MC-W and M2-E indicate organic matter contributions as terrigenous, marine and marine, respectively.

Carbon preference index (CPI) is measured using peak heights or areas from gas chromatography. Although CPI is specific for maturity, it is also affected by other processes, such as source and biodegradation. The relative abundance of odd versus even carbon numbered $n$-alkanes can be used to obtain an approximate estimate of the thermal maturity of petroleum. CPI is calculated using the formula below, as presented in Table 7.

$\mathrm{CPI}=\frac{2(\mathrm{C} 23+\mathrm{C} 25+\mathrm{C} 27+\mathrm{C} 29)}{\mathrm{C} 22+2(\mathrm{C} 24+\mathrm{C} 26+\mathrm{C} 28)+\mathrm{C} 30}$

Odd preference CPI values are above 1.0, whilst even preference values are below 1.0, where significant deviations from 1.0 indicate low thermal maturity, such as the sample M3-SE with a CPI value of 3.08. CPI values of 1.0 are suggestive that an oil or rock extract is thermally mature,

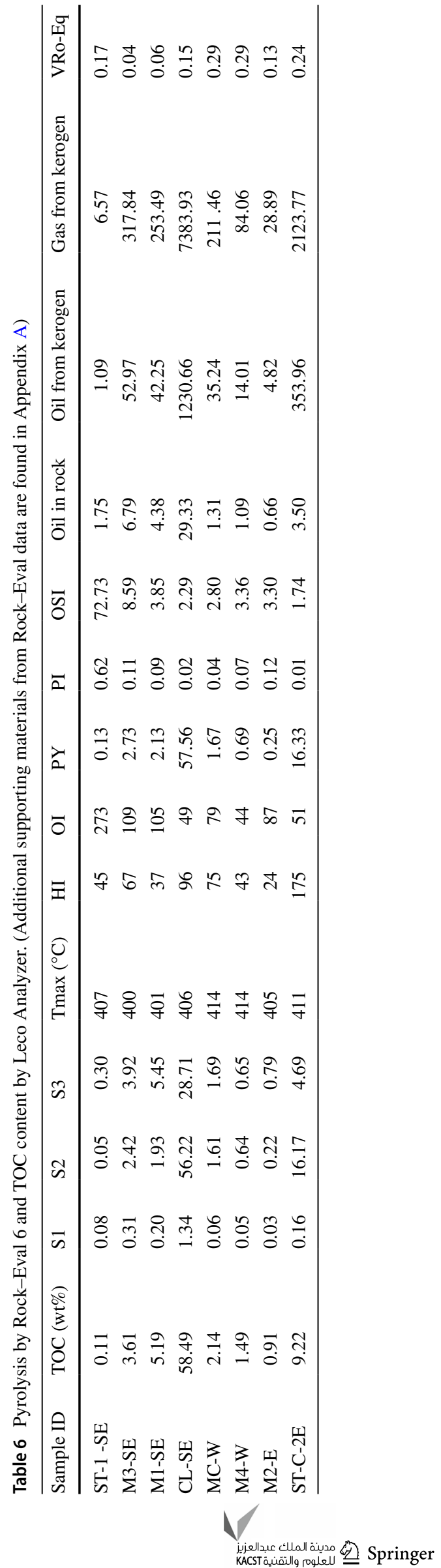


Fig. 9 Cross-plot of phytane/n$\mathrm{C}_{18}$ versus pristane $/ n-\mathrm{C}_{17}$ indicating the depositional

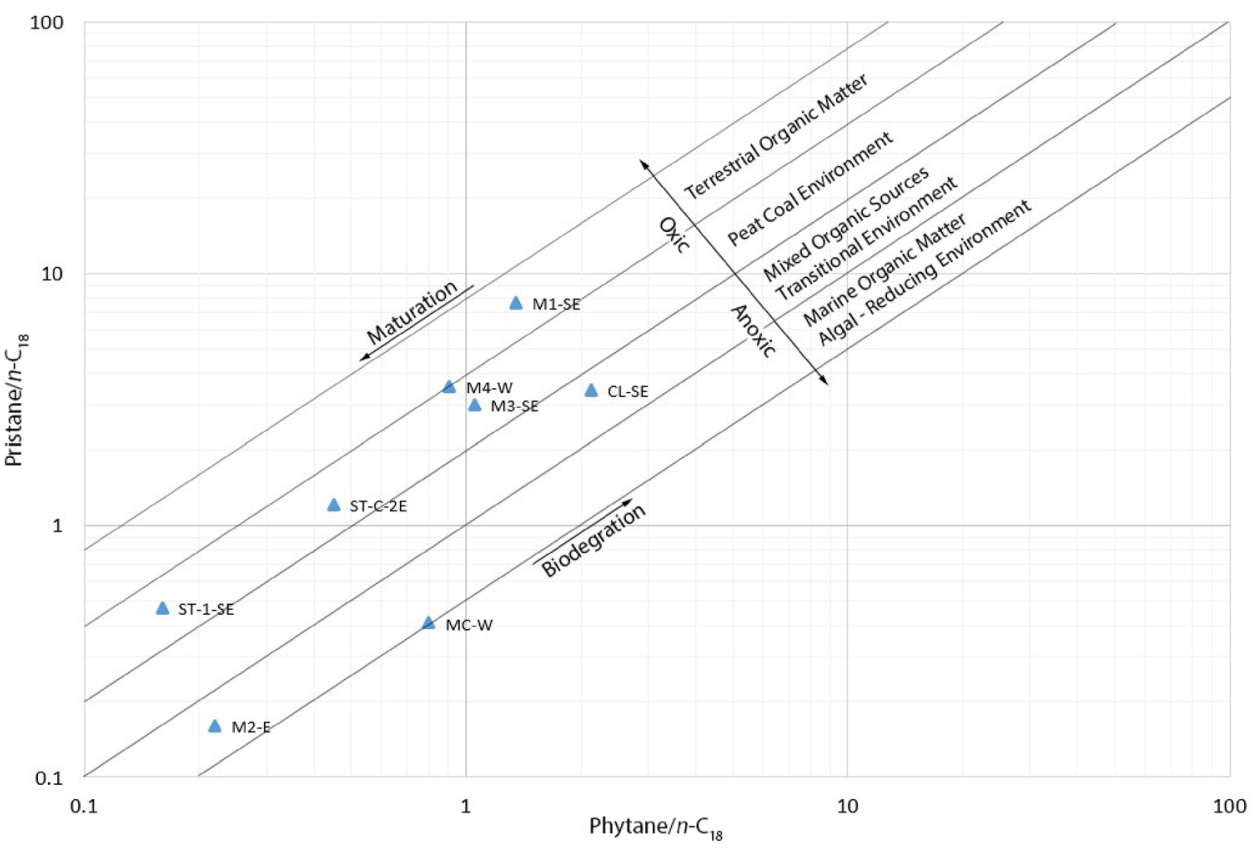

Table 7 Source richness and weight percent TOC

\begin{tabular}{lll}
\hline Richness & TOC (wt. \%) & Samples \\
\hline Poor & $0.0-0.5$ & ST-1-SE \\
Fair & $0.5-1.0$ & M2-E \\
Good & $1.0-2.0$ & M4-W \\
Very good & $>2.0$ & CL-SE, M1-SE, \\
& & MC-W, ST-C-2E, \\
& & M3-SE \\
\hline
\end{tabular}

whilst less than 1.0 values are uncommon and represent lowmaturity oils or bitumens from carbonate or hypersaline environments. Oils and source rocks with CPI about 1 may arise from a predominance of marine input and/or thermal maturation (Peters et al. 2005). Samples ST-C-2E and ST1-SE have closest values to 1.0 CPI. Sample M2-E has a CPI value below 1 which potentially indicates low thermal maturity, as shown in Table 8.

The gas chromatograms are depicted in Fig. 10.

\section{Rock-Eval pyrolysis}

Source rock quality of organic matter determines whether kerogen is suitable to produce either oil, gas or virtually nothing. Types I and II refer to oil-prone kerogen; type III is gas-prone. Quality can be evaluated based on the hydrogen index $\left(\mathrm{S}_{2} / \mathrm{TOC}\right.$ ) and $\mathrm{S}_{2} / \mathrm{S}_{3}$ (Horsfield and Rullkotter 1994). Quantity is measured as total organic carbon content (TOC) in weight percent.

A modified van Krevelen diagram is depicted in Fig. 11 to pinpoint the kerogen type from the gathered samples.

Pseudo van Krevelen diagram based on oxygen and hydrogen index of the samples shows type IV kerogen for M4-W, ST-1-SE, M3-SE, MC-W, M1-SE and M2-E. They can be considered as having low hydrogen, degraded organic matter referred to as type IV which do not yield significant amounts of hydrocarbon. Type IV kerogen is dominated by inertinite and contains predominantly higher-plant organic matter that was recycled or oxidized extensively during deposition. It is known as dry-gas-type kerogen.
Table 8 The correlation of vitrinite reflectance values with diagenetic and thermal maturity stages (after Beaumont and Foster (1988) and Peters and Cassa (1994))

\begin{tabular}{llllll}
\hline Sample ID & Mean Rm \% & $\begin{array}{l}\text { Standard } \\
\text { deviation }\end{array}$ & Counts & Diagenetic stage & $\begin{array}{l}\text { Thermal } \\
\text { maturity } \\
\text { for oil }\end{array}$ \\
\hline ST-1-SE & 0.528 & 0.106 & 40 & Catagenesis & Immature \\
M3-SE & 0.423 & 0.147 & 30 & Diagenesis & Immature \\
CL-SE & 0.356 & 0.017 & 50 & Diagenesis & Immature \\
MC-W & 0.572 & 0.098 & 50 & Catagenesis & Immature \\
M4-W & 0.584 & 0.248 & 30 & Catagenesis & Immature \\
ST-C-2E & 0.400 & 0.031 & 50 & Diagenesis & Immature \\
\hline
\end{tabular}




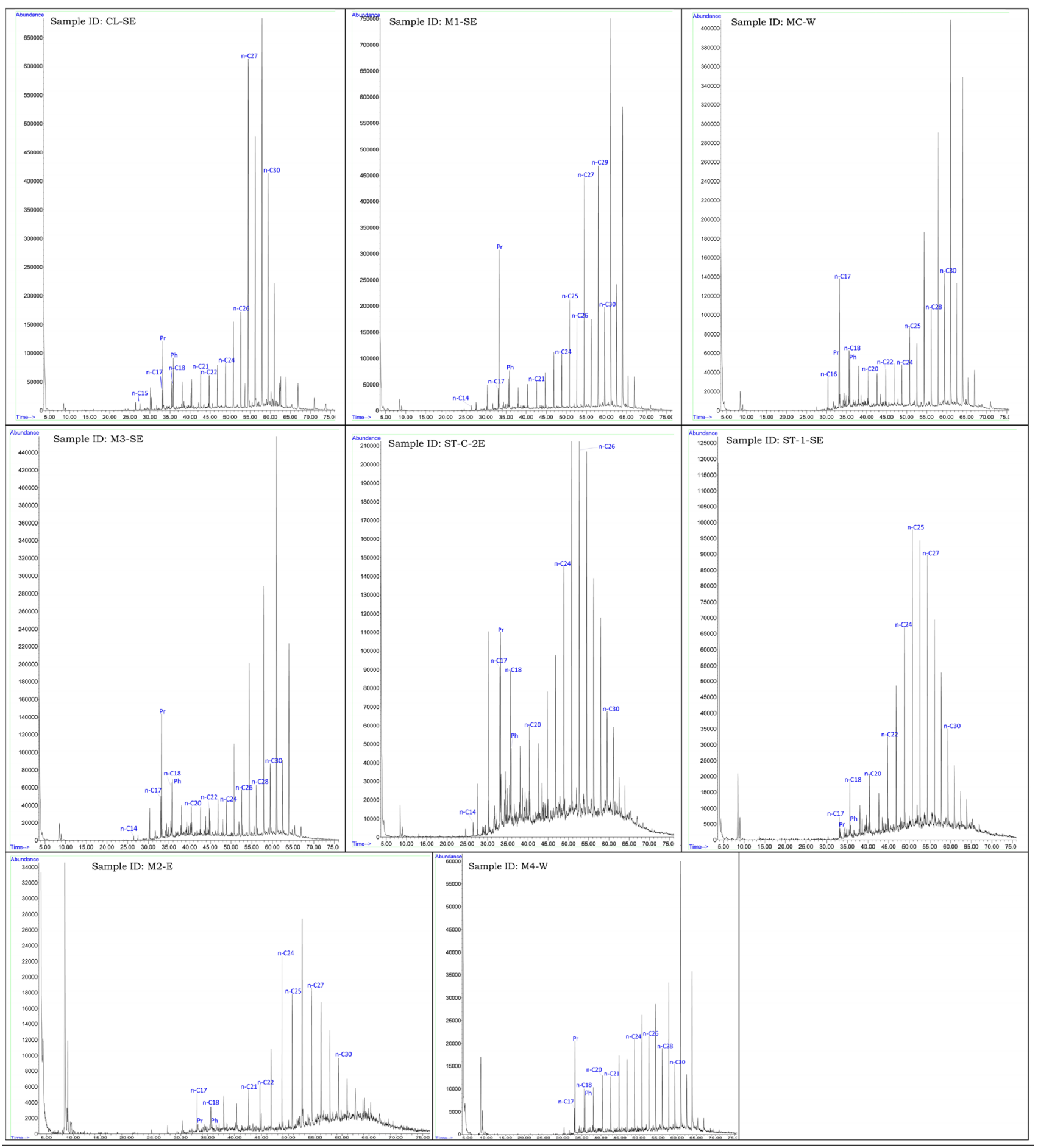

Fig. 10 Gas chromatograms of CL-SE, MC-W, MC-W, M3-SE, ST-C-2E, M2-E, M1-SE, ST-1-SE and M4-W

Though the kerogen is predominantly type IV, the presence of some macerals of some analysed samples indicates that the organic matter in the sediments may also produce oil, albeit in limited quantity. Coaly sandstone sample ST-C-2E has mixed kerogen. And coal sample CL-SE is mainly gasprone-kerogen type III which contains higher-plant organic matter dominated by vitrinite macerals. Kerogen type III is common in, but not restricted to, paralic marine settings 
Fig. 11 A modified van Krevelen diagram based on the samples showing relationship between oxygen and hydrogen index as well as the types of kerogen

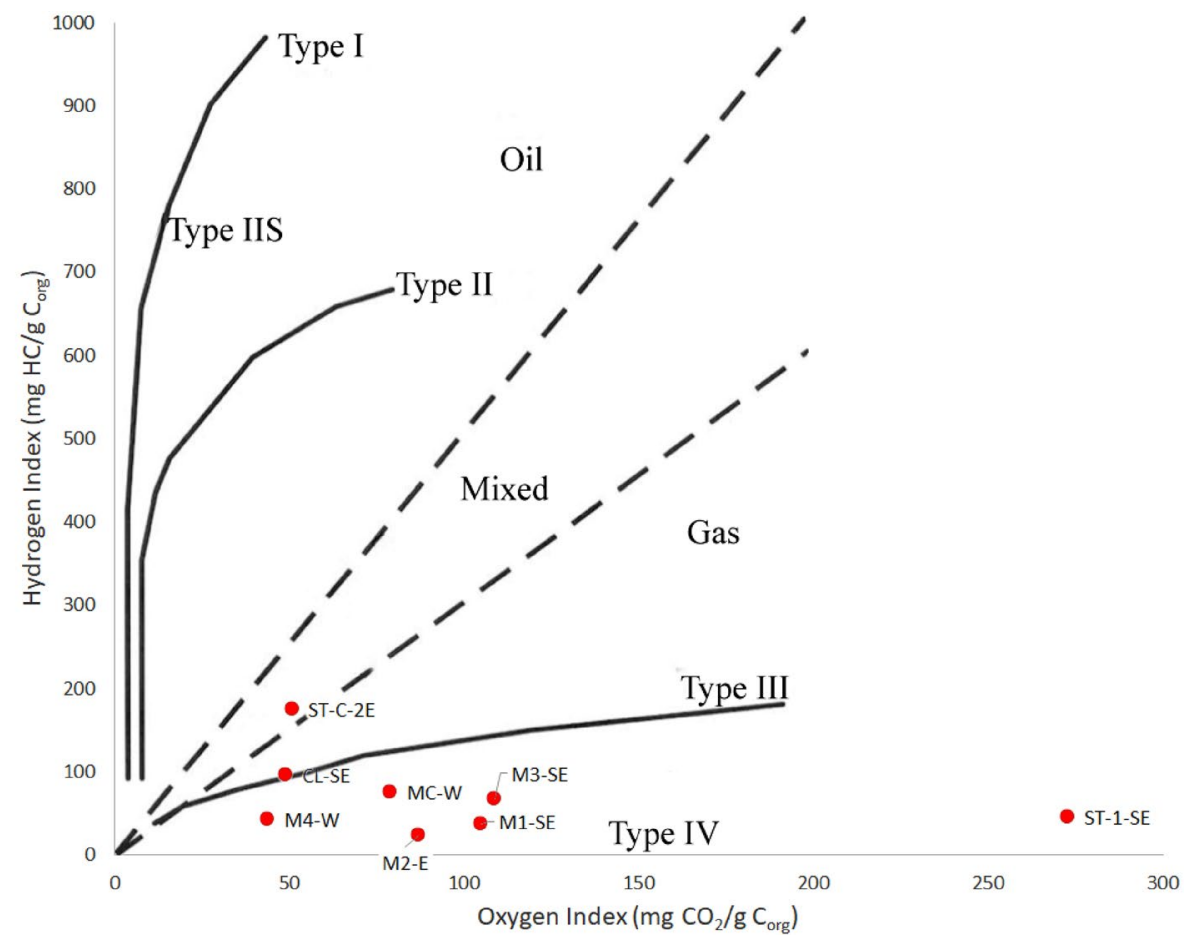

(Peters et al. 2005), such as deltas, estuaries and near coastlines. Continental organic matter, which is limited to quick burial and generates moderate potential for oil, corresponds to kerogen type III (Tissot and Welte 1984).

\section{Total organic carbon (TOC)}

Table 8 shows source richness interpretation of weight percent TOC based on Peters (1986).

Only one sample from Bukit Song south-east (ST-1-SE) shows poor source richness based on TOC interpretation. CL-SE, M1-SE, and M3-SE from Bukit Song south-east have very good source richness.

TOC, however, is not a lucid gauge of petroleum potential. For example, some Tertiary deltaic marine shales contain up to $5 \mathrm{wt}$. \% TOC but generate hardly any petroleum because the organic matter is gas-prone or inert (Peters and Cassa 1994). A high TOC is a characteristic of a good source rock, though the type of organic matter is important too as far as oil or gas generation is concerned. Therefore, TOC by itself is not necessarily a good indicator of how much hydrocarbon a sediment can generate. As such, an indicator of hydrogen present in the organic matter is used to supplement TOC finding. Hydrogen content can be estimated indirectly from Rock-Eval data. Rock-Eval estimates the organic matter's hydrogen content with the $S_{2}$ value, a quantification of the amount of hydrocarbon formed during the thermal decomposition of the kerogen which is measured in milligrams of hydrocarbons per gram of rock. Therefore, by combining TOC and $\mathrm{S}_{2}$, the amount of hydrogen associated with the organic matter can be corroborated: higher $S_{2}$ values represent the better source rocks and will generate more hydrocarbons for similar TOC values. Figure 12 combines these two parameters, showing that there is limited hydrocarbon potential for most of the samples.

\section{Pyrolysis gas chromatography (Py-GC)}

The supplemental use of the geochemical data pyrolysis-gas chromatography (Py-GC) is a helpful way in interpreting kerogen mixtures. Py-GC differs from the Rock-Eval method in that parts of the material making up the $S_{2}$ peaks are separately analysed by gas chromatography. Py-GC analysis provides qualitative and quantitative chemistry of the thermal decomposition products of the kerogen. Such information is a direct index of the kerogen type and types of hydrocarbons that can be generated by the kerogen during the maturation process (Giraud 1970). When jointly used with Rock-Eval data, it can provide more accurate evaluation of kerogen type.

The pyrolysis products of the oil-prone type I and II kerogens extend out to the high molecular weight range of compounds. Type I kerogen produces abundant long-chained $n$-alkanes and $n$-alkenes in the chromatogram, whereas type 
Fig. 12 A crossplot of the samples pointing that higher $\mathrm{S}_{2}$ values represent the better source rocks and will generate more hydrocarbons. Combining TOC and $\mathrm{S}_{2}$ gives an idea of how much organic matter is present and how much hydrogen is associated with it

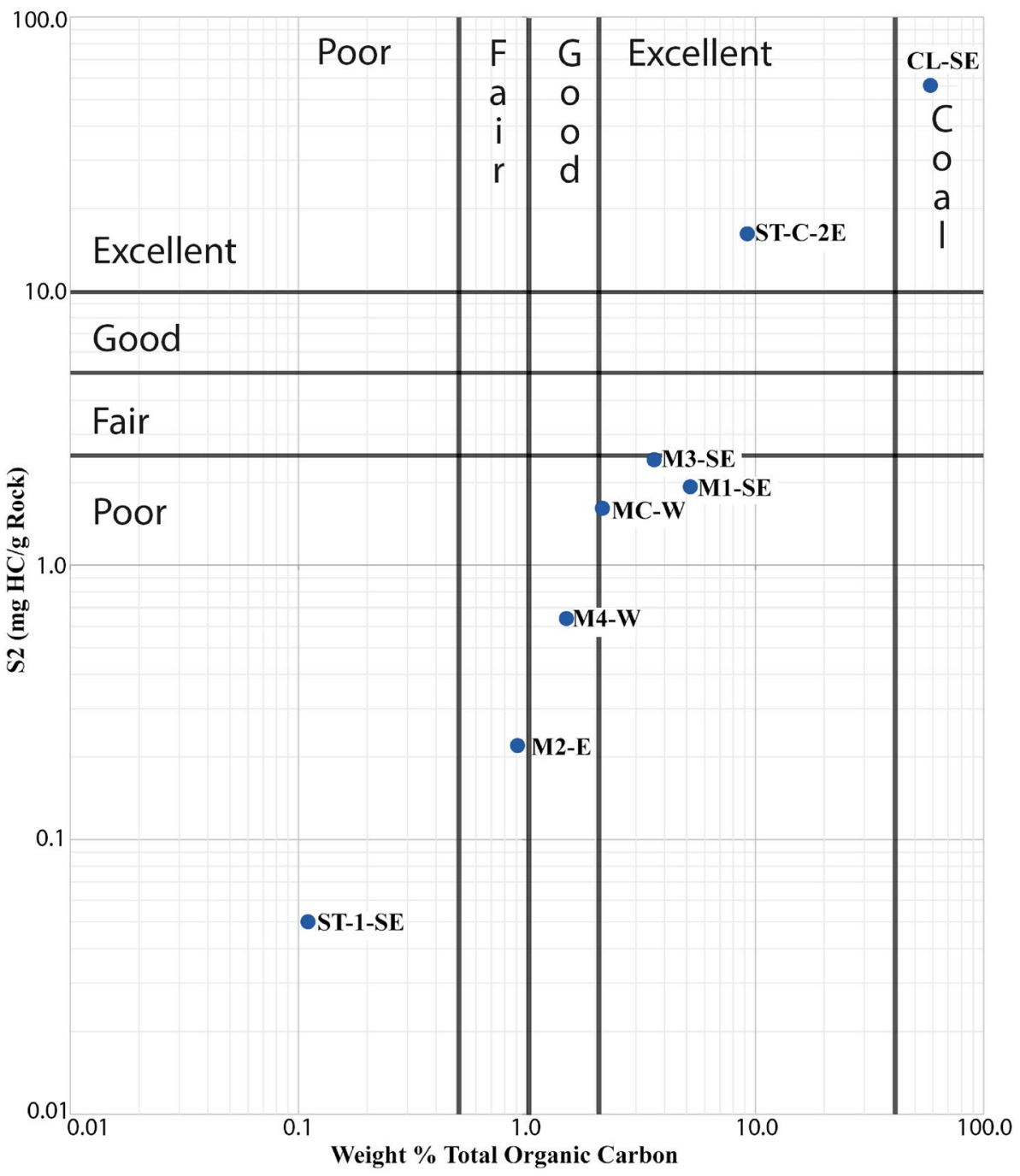

II kerogen produces more naphthenic compounds. Type III gas-prone kerogen shows the bulk of the pyrolysis products confined to the low molecular weight end $(<\mathrm{C} 10)$ of the chromatogram. The results are produced in Fig. 13.

Based on Py-GC data, samples M4-W, ST-1-SE, M3-SE, MC-W, M1-SE and M2-E do not seem to have potential for hydrocarbon generation as there is little signal during pyrolysis gas chromatographic analysis. This can be confirmed from van Krevelen diagram based on Rock-Eval data of the samples as they are plotted within kerogen type IV, which means there is too little hydrogen to allow for oil or gas generation. Py-GC data shows the gas-proneness of the sample CL-SE as it shows the bulk of the pyrolysis products confined to the low molecular weight end $(<\mathrm{C} 10)$ of the chromatogram. Type III kerogen of CL-SE is also confirmable based on the Rock-Eval data stated earlier. Sample
ST-C-2E shows some high concentration of the $>$ C15 compounds. Based on van Krevelen, ST-C-2E is within mixed range and other parameters indicate higher hydrocarbon generating potential from ST-C-2E than other samples.

\section{Discussion}

Although some samples from this study showed excellent petroleum potential based on the amount of extracted bitumen, there are parameters, such as maceral analysis, that indicated most samples did not have promising petroleum generating potential.

Hydrocarbons are expelled from the source rock when organic matter-rich source rocks have reached maturation through sufficiently raised temperatures and pressures (Jahn 

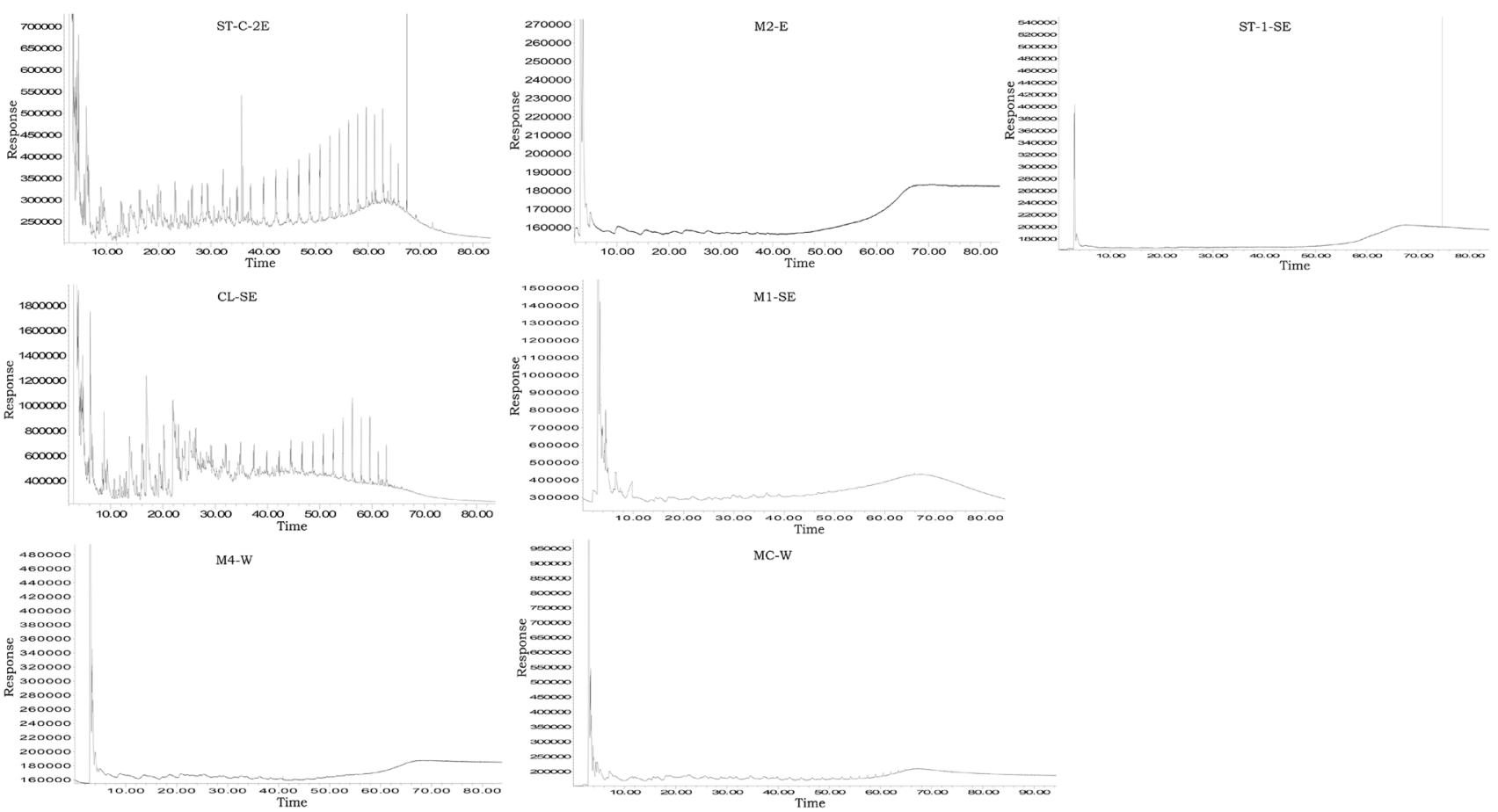

Fig. 13 Py-GC of ST-C-2E, CL-SE, M2-E, M1-SE, M3-SE, M4-W, MC-W and ST-1-SE

et al. 2008). Sundaland has a hot, but thin lithosphere. The Lambir Formation, which is a small part of Sundaland, has a maximum thickness of $1.6 \mathrm{~km}$ and the source rocks from the results of this study mostly appear to have insufficient thermal maturity, despite the reported high surface heat flow values of the interior of Sundaland. Vitrinite reflectance values of none of the samples were greater than $0.6 \%$ at which point commencement of oil generation is expected. The existence of greenish fluorescing resinite maceral corroborated with the immaturity of the coaly samples. The presence of macerals, such as sporinite and cutinite, means a higher thermal maturity is needed for the release of hydrocarbons. The peak conversion of kerogen takes place at a temperature of around $100{ }^{\circ} \mathrm{C}$, whilst a temperature of more than $130{ }^{\circ} \mathrm{C}$ would result in cracking of oil and production gas. The samples analysed in this paper tend to show insufficient palaeotemperature overall.

As gathered from X-ray diffraction, although illite was detected, the lack of smectite and tobelite may imply insufficient thermal maturity of source rock suggesting the lack of potential for oil generation. The samples that were analysed for XRD also showed to be poor source rocks based on $\mathrm{S}_{2}$ values and TOC. Existence of kaolinite and illite in these samples is a potential source of reduction in porosity, hence inhibiting the movement of hydrocarbons.
None of the samples were within oil-generative window based on the $T_{\max }$ values and the modified van Krevelen diagram. Based on the modified van Krevelen diagram, significant mixing between kerogen types seems unlikely. Based on $\mathrm{Pr} / \mathrm{Ph}, \mathrm{CPI}$, and $\mathrm{Ph} / n-\mathrm{C}_{18}$ versus $\mathrm{Pr} / n-\mathrm{C}_{17}$, the sample M2-E from east of Bukit Song showed marine input and high thermal maturity. Whilst ST-1-SE from south-east of Bukit Song showed same properties, TOC and $\mathrm{S}_{2}$ values were not indicative of high maturity, neither for M2-E nor for ST-1-SE. M3-SE indicated oxic conditions and insufficient maturity. MC-W showed marine input with moderate maturity based on Pr/Ph. M1-SE had terrestrial input with low maturity. Vitrinite reflectance values of ST-1-SE, M3-SE and MC-W showed thermal immaturity for oil generation.

TOC findings were corroborated with $\mathrm{S}_{2}$ values as TOC value per se is not completely accurate in judging better or worse source rocks and hydrocarbon generation potential. Even though five samples showed very good TOC values (>2.0), hence a promising potential source rock, combining results with $S_{2}$ resulted in recognition of only samples $\mathbf{C L}$ SE and ST-C-2E as excellent source rocks. ST-C-2E also had a CPI value of 1.12 .

Maceral analysis showed high abundance of vitrinite for samples CL-SE and ST-C-2E. CL-SE is interpreted as having kerogen type III to IV, but more likely to be gas-prone 
due to the dominant abundance of vitrinite. CL-SE has many features associated with terrestrial depositional environment, with some marine $\mathrm{OM}$ contribution too based on the maceral analysis. $\mathrm{Pr} / n-\mathrm{C}_{17} \mathrm{vs}$. $\mathrm{Ph} / n-\mathrm{C}_{18}$ points to mixed origin as well.

ST-C-2E shows some evidence of liquid hydrocarbon potential or a higher hydrogen content based on the existence of liptinite macerals, such as suberinite, resinite and cutinite, but still can be regarded to be at immature stage: it has low vitrinite reflectance. There are greenish fluorescing resinite macerals in both CL-SE and ST-C2E suggestive of immaturity. Both samples recorded highest amount of TOC of the analysed samples and showed high abundance of pyrite.

Signal intensity from gas chromatograms of most samples show an accentuated intensity towards higher molecular weight compounds of $n$-alkanes distribution region, indicating contribution of terrestrial plant waxes. Sample MC-W indicates a dominance of intermediate molecular weight compounds, indicating a higher algal influence.

Finally, it is important to note the assessment of this study is based on a limited number of outcrop samples. More detailed and a broader analysis requires more samples, including from the subsurface, within the region. There could be significant variations both vertically and horizontally from the sampling locations as regards a source rock's richness and kerogen type.

\section{Conclusions}

The result of this study showed an overall immaturity of samples regarding hydrocarbon generating potential. Depositional environment can be described as oxic terrestrial and peat coal environment with some marine contribution.

Two samples were found to have better hydrocarbon generation potential. Sample ST-C-2E has very-good-to-excellent petroleum potential (quantity) whose hydrocarbons and extracted bitumen amounts also agree with organic matter parameters, namely TOC (above 4 wt.\%) and $S_{2}$ value of about $16 \mathrm{mg} / \mathrm{g}$ rock. Based on the same mentioned parameters, CL-SE can be considered as having very good petroleum potential. However, based on its vitrinite reflectance as well as its $\mathrm{Ph} / n-\mathrm{C}_{18}$ versus $\mathrm{Pr} / n$ $\mathrm{C}_{17}$ values, it is immature. ST-C-2E, in comparison, shows slightly higher maturity, which is in agreement when compared the two samples' CPI values. Significant migration of hydrocarbons cannot be expected from samples according to gas chromatograms as longer-chained atoms were still dominantly unbroken. All samples analysed for their vitrinite reflectance are immature with some variations as regards maturity index of $\mathrm{Ph} / n-\mathrm{C}_{18}$ versus $\mathrm{Pr} / n-\mathrm{C}_{17}$ parameter. There was a greater concentration within peat coal environment for samples from east, west and S.E. Bukit Song. Samples from south-east mainly correspond to oxic depositional environment. The presence of pyrite, suggestive of an anoxic environment of deposition, was especially common in CL-SE sample whose phytane $/ n-\mathrm{C}_{18}$ versus pristane $/ n-\mathrm{C}_{17}$ plot also corresponds to anoxic depositional environment. Except samples CL-SE and ST-C-2E, all samples indicate being inert-kerogen type IV—based on the van Krevelen diagram. Based on previous works in the Lambir Formation, similar to this study, most contribution from marine sources was minor. Significant input from biomarkers, however, is needed to understand source organic matter influence better.

\section{Appendix A}

See (Fig. 14). 


\section{Sample ID: CL-SE}
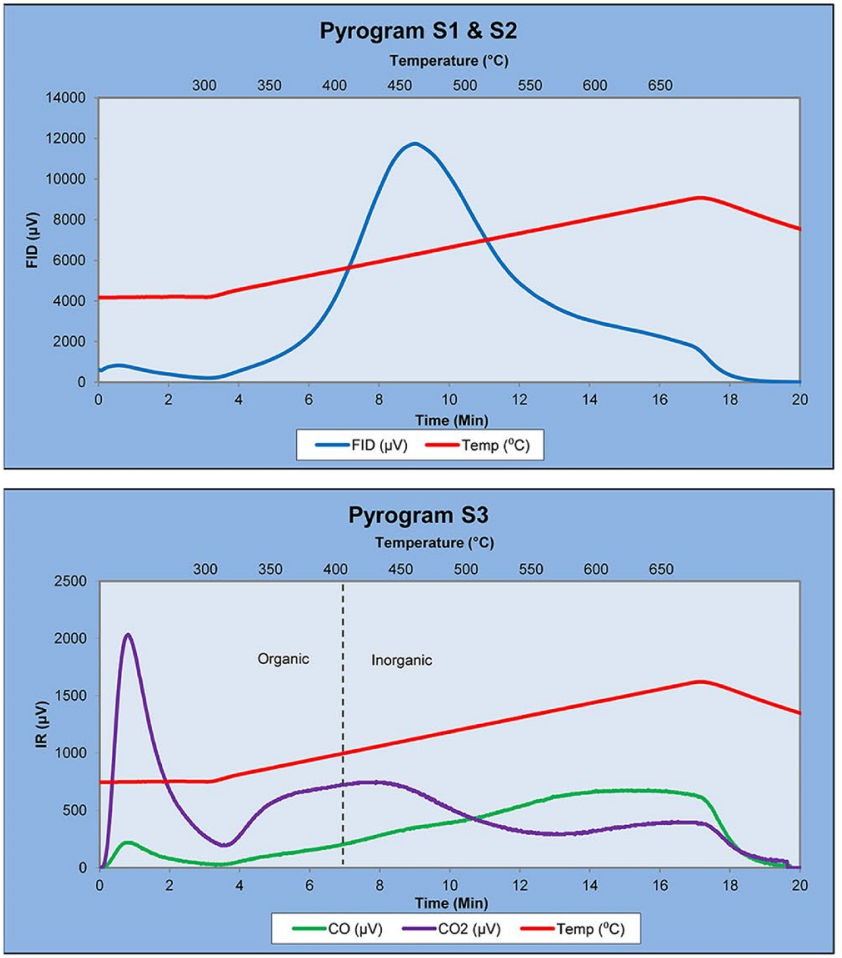

Sample ID: M1-SE
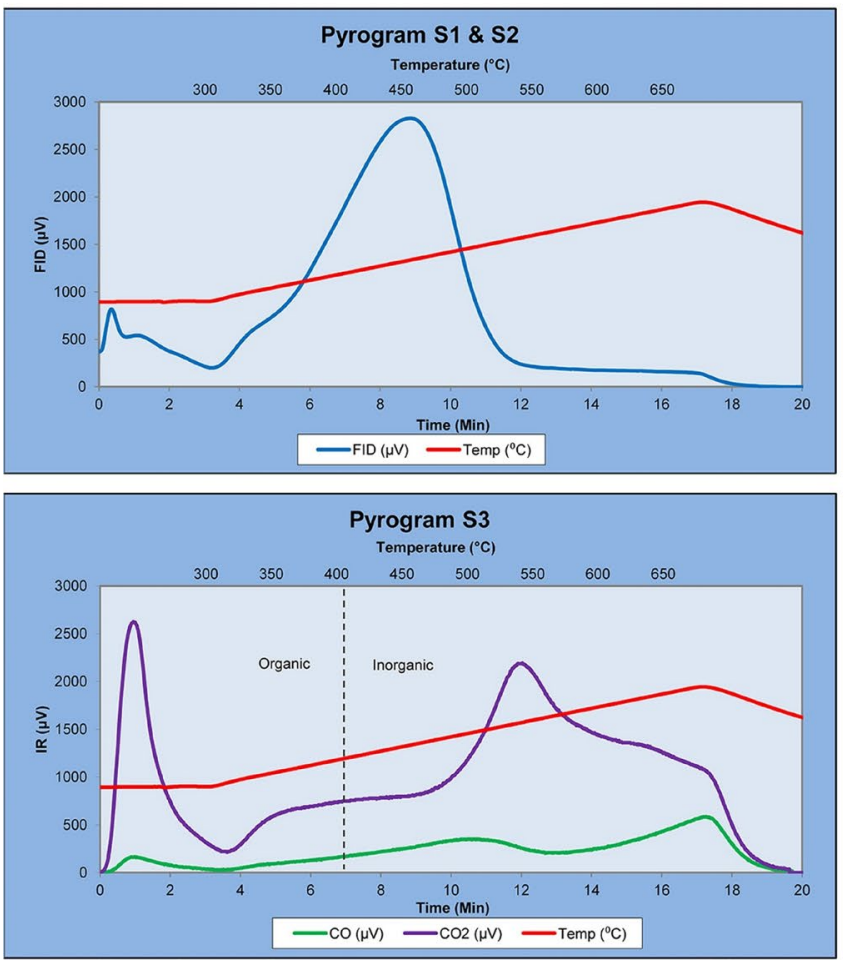

\section{Sample ID: M2-E}
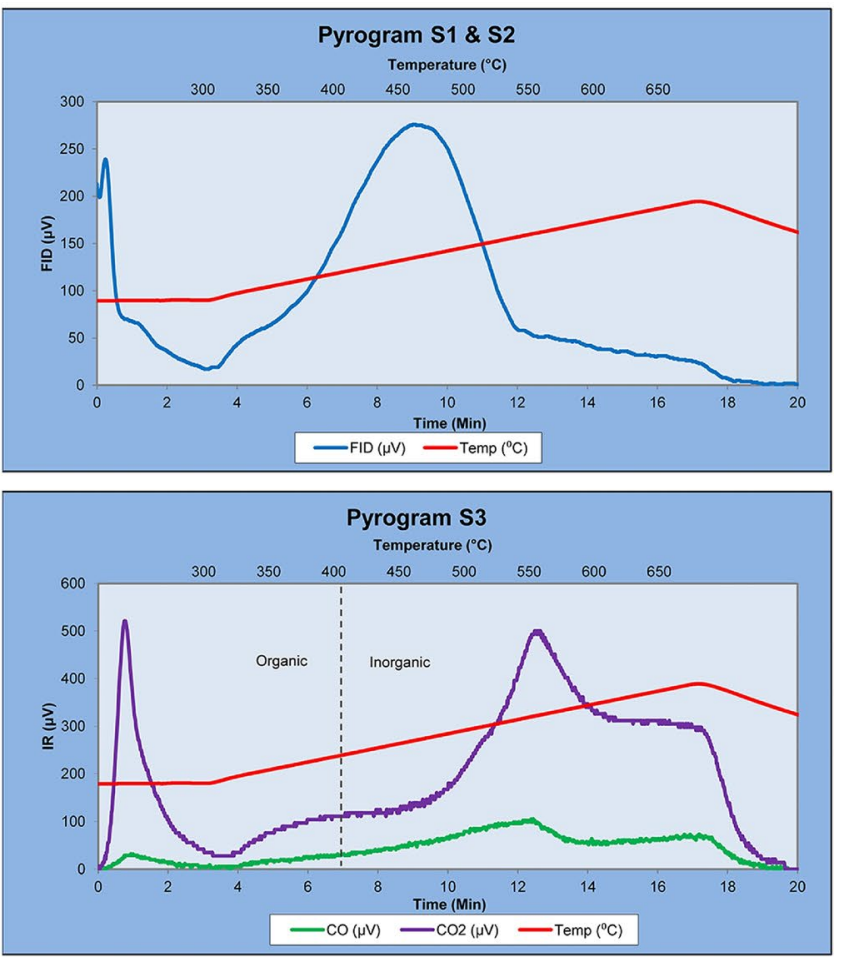

Sample ID: MC-W
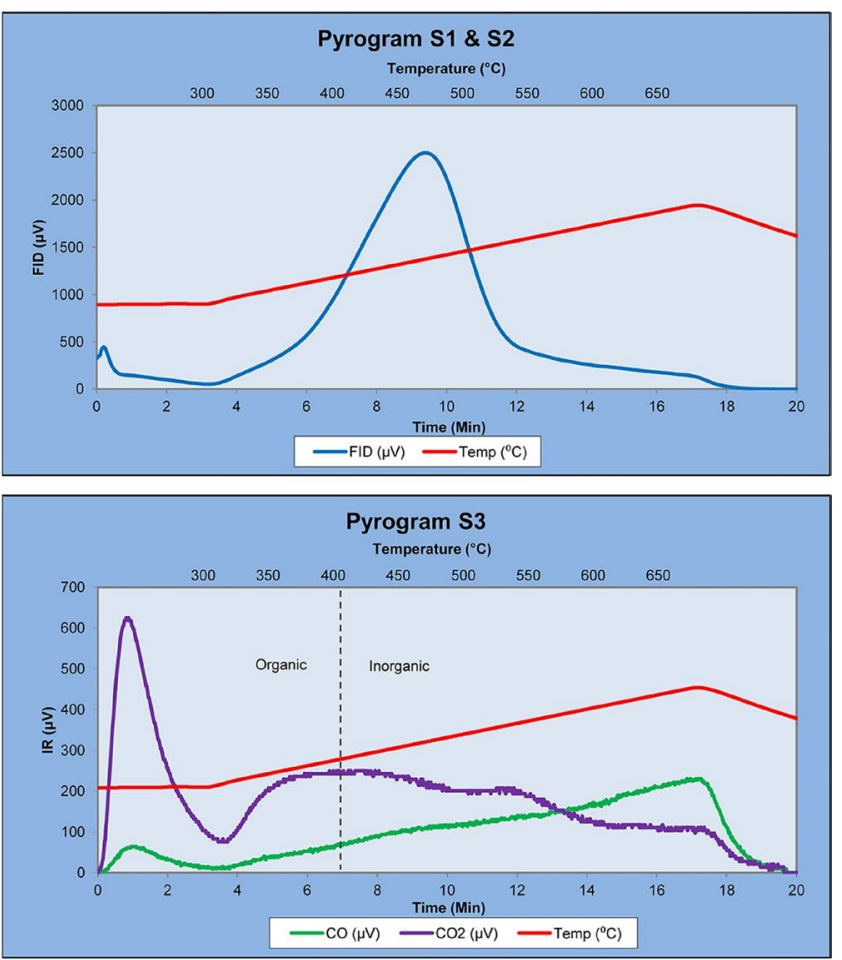

Fig. 14 Supplements regarding Rock-Eval data: The pyrograms of a few samples have a broad S2 peak and a few show a high temperature 'shoulder' 


\section{Sample ID: ST-C-2E}
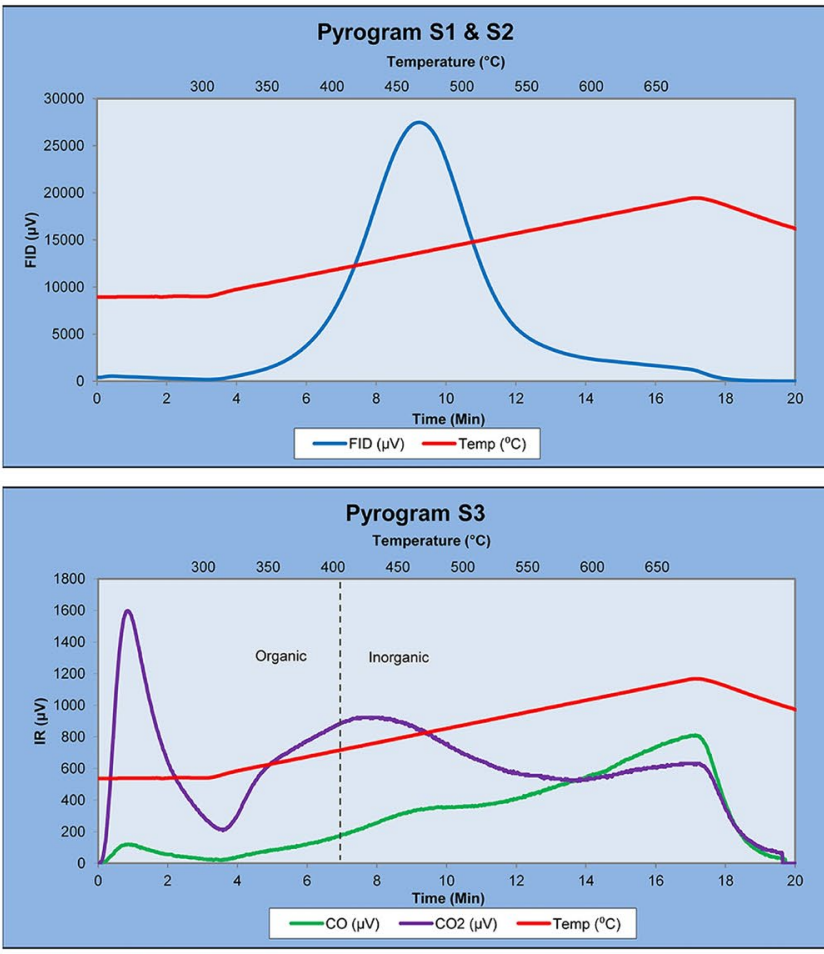

Sample ID: M4-W
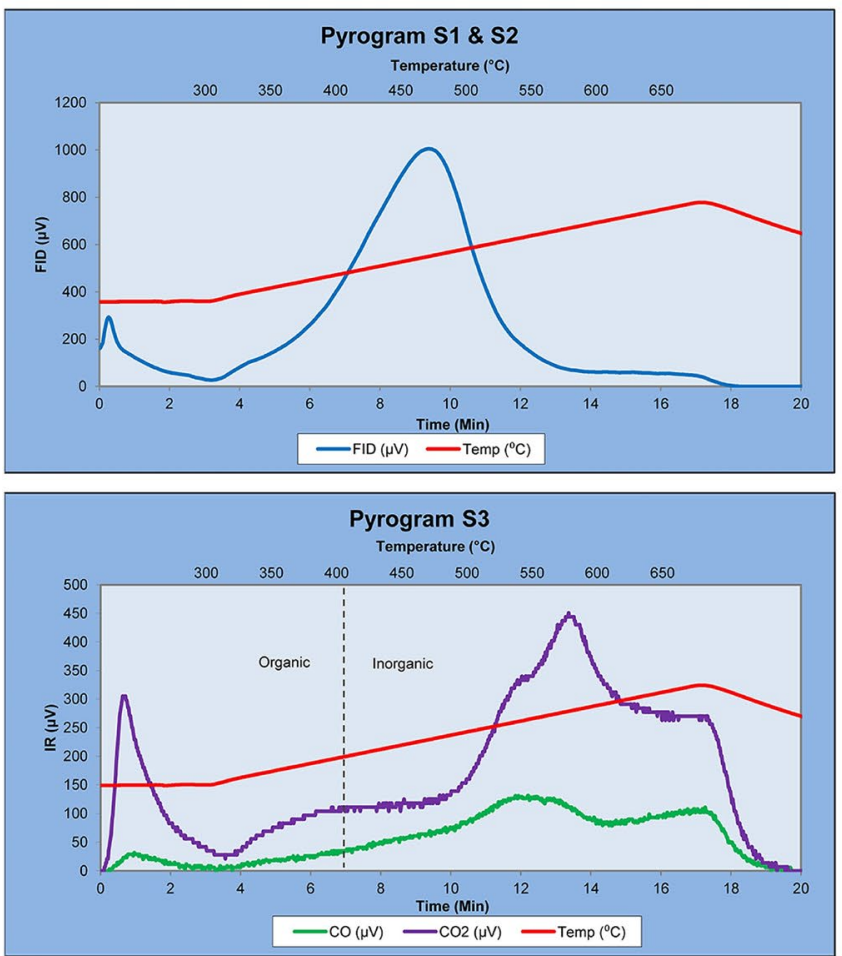

Sample ID: M3-SE
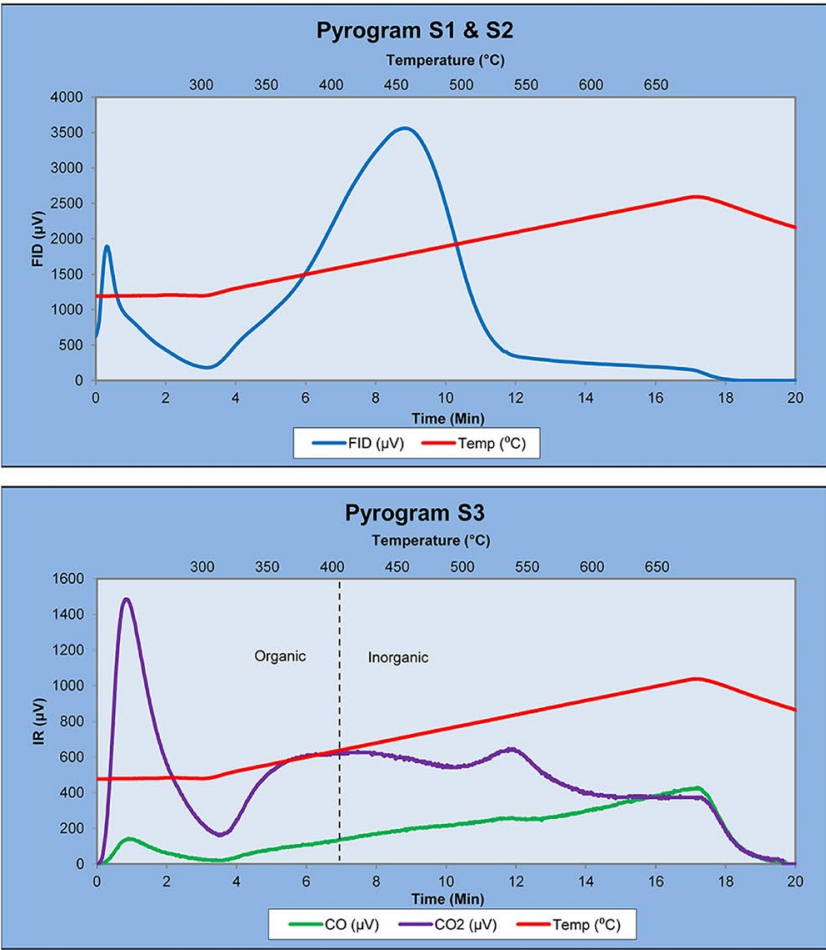

Sample ID: ST-1-SE
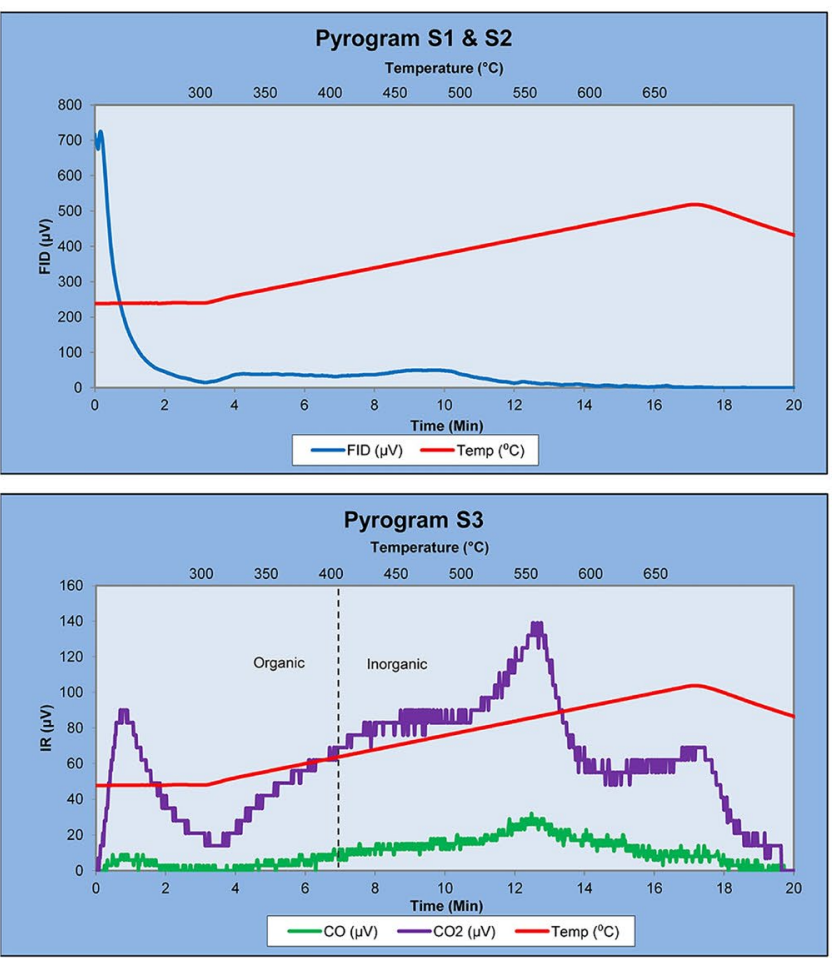

Fig. 14 (continued) 


\section{Appendix B}

See (Fig. 15).

Fig. 15 Vitrinite reflectance histograms

Vitrinite reflectance histograms:
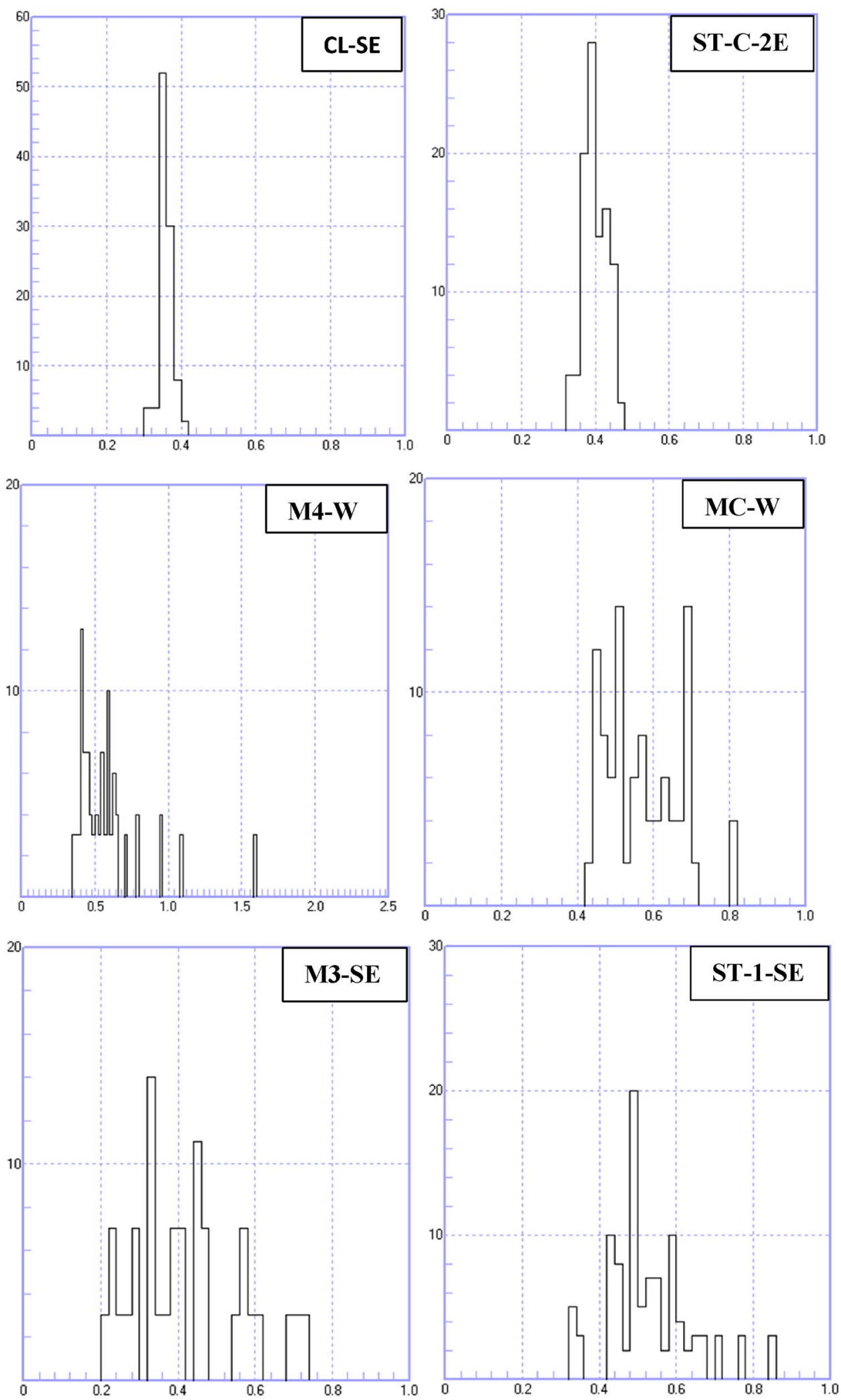
Acknowledgements I wish to thank Professor Wan Hasiah Abdullah and Doctor Yousif Mohammed Makeen who were willing to oversee and supervise my work. I am grateful to their discussions and comments that benefited this paper. I am also thankful to them as they have helped to strengthen and criticize the earlier drafts of this paper. The author is grateful to the department of Geology at the University of Malaya for providing all the necessary scientific instruments needed to complete this paper. Dr Iskandar Taib, Ms Fasha, Mr Shahrom, Mrs Zaleha, and Mr Zamri are thanked for providing me access and assistance to laboratory tools.

Funding The author received no financial support for the research, authorship, and/or publication of this paper.

\section{Declarations}

Conflict of interest The author declares that there are no known competing financial interests or personal relationships that could have appeared to influence the work reported in this paper.

Open Access This article is licensed under a Creative Commons Attribution 4.0 International License, which permits use, sharing, adaptation, distribution and reproduction in any medium or format, as long as you give appropriate credit to the original author(s) and the source, provide a link to the Creative Commons licence, and indicate if changes were made. The images or other third party material in this article are included in the article's Creative Commons licence, unless indicated otherwise in a credit line to the material. If material is not included in the article's Creative Commons licence and your intended use is not permitted by statutory regulation or exceeds the permitted use, you will need to obtain permission directly from the copyright holder. To view a copy of this licence, visit http://creativecommons.org/licenses/by/4.0/.

\section{References}

Barker CE (1991) An update on the suppression of vitrinite reflectance. Soc Org Petrol 8:8-11

Barker CE (1996) A comparison of vitrinite reflectance measurements made on whole-rock and dispersed organic matter concentrate mounts. Org Geochem 24:251-256

Barker CE, Pawlewicz MJ (1993) An empirical determination of the minimum number of measurements needed to estimate the mean random vitrinite reflectance of disseminated organic matter. Org Geochem 20(6):643-651

Beaumont EA, Foster NH (1988) Geochemistry: Treatise of Petroleum Geology.In: Tulsa: American association of petroleum geologists(Reprint Series \#8), pp 660

Bjørlykke K (2015) Petroleum geoscience: from sedimentary environments to rock physics, 2nd edn. Springer, Berlin, Heidelberg, ISBN 978-3-642-34131-1

Chilingar GV, Buryakovsky LA, Eremenko NA, Gorfunkel MV (2005) Developments in Petroleum Science 52. Elsevier B.V., pp 120 121. ISBN-13: 978-0-444-52053-1

Davey RJ, Rogers J (1975) Palynomorph distribution in recent offshore sediments along two traverses off South West Africa. Mar Geol 18(4):213-225

Davis A, Russell SJ, Rimmer SM, Yeakel JD (1984) Some genetic implications of silica and aluminosilicates in peat and coal. Int $\mathbf{J}$ Coal Geol 3(4):293-314

Dembicki H (2009) Three common source rock evaluation errors made by geologists during prospect or play appraisals. AAPG Bull 93(3):341-356
Drits VA, Lindgreen H, Sakharov BA, Jakobsen HJ, Salyn AL, Dainyak LG (2002) Tobelitization of smectite during oil generation in oilsource shales. Application to North Sea illite-tobelite-smectitevermiculite. Clays Clay Miner 50:82-98

Giraud A (1970) Application of pyrolysis and gas chromatography in sedimentary rocks. AAPG Bull 54(3):439-455

Guo Y, Bustin RM (1998) Micro-FTIR spectroscopy of liptinite macerals in coal. Int J Coal 36(3/4):259-275

Hackley PC, Araujo CV, Borrego AG, Bouzinos A, Cardott BJ, Cook AC, Eble C, Flores D, Gentzis T, Gonçalves PA, Filho JGM, Hámor-Vidó M, Jelonek I, Kommeren K, Knowles W, Kus J, Mastalerz M, Menezes TR, Newman J, Oikonomopoulos IK, Pawlewicz M, Pickel W, Potter J, Ranasinghe P, Read H, Reyes J, De La Rosa G, Rodriguez IV, Fernandes A, de Souza I, Suárez-Ruiz I S, Valentine BJ (2015) Standardization of reflectance measurements in dispersed organic matter: results of an exercise to improve interlaboratory agreement. Marine Pet Geol 59:22-34

Haile NS, Ho CK (1991) Geological field guide: Sibu-Miri traverse, Sarawak (24 September - 1 October 1991). Petronas Petroleum Research Institute, p 37

Hall R (2017) Southeast Asia: new views of the geology of the malay archipelago. Annu Rev Earth Planet Sci 45:331-358

Hall R, Morley CK (2004) Continent-Ocean Interactions within the East Asian Marginal Seas. In: Geophysical monograph series, pp 78

Horsfield B, Rullkotter J (1994) Diagenesis, catagenesis, and metagenesis of organic matter. In: Magoon LB, Dow WG (Eds.), The petroleum system - from source to trap: AAPG Memoir 60, pp. 189-192

Hutchison CS (2005) Geology of North-West borneo: sarawak. Elsevier Science, Brunei and Sabah

ICCP (1998) The new vitrinite classification (ICCP System 1994). Fuel 77(5):349-358

ICCP (2001) The new inertinite classification (ICCP System 1994). Fuel 80(4):459-471

Jahn F, Cook M, Graham M (2008) Hydrocarbon exploration and production, 2 (ed), Vol. 55, Elsevier Science

Khorasani GK, Murchison D (1988) Order of generation of petroleum hydrocarbons from liptinitic material with increasing maturity. Fuel 67(8):1160-1162

Louis M, Tisso BP (1967). Influence de la temperature et de la pression sur la formation des hydrocarbures dans les argiles a kerogen. In: Proc 7th world petroleum congr, Mexico, pp. 47-60

Peters KE (1986) Guidelines for evaluating petroleum source rock using programmed pyrolysis. In: Vol. 70. AAPG, pp 318-329

Peters KE, Cassa MR (1994) Applied Source rock geochemistry. In: The petroleum system-from source to trap. American Association of Petroleum Geologists, pp 96

Peters KE, Walters CC, Moldowan JM (2005) The biomarker guide: biomarkers and isotopes in petroleum exploration and earth history, Vol. 2. Cambridge University Press.

Philippi G (1965) On the depth, time and mechanism of petroleum generation. Geochim Cosmochim Acta 29(9):1021-1049

Pollack HN, Hurter S, Johnson JR (1993) Heat flow from the Earth's interior: analysis of the global data set. Rev Geophys 31(3):267-280

Powell TG, Boreham CJ (1991) Petroleum genration and source rock assessment in terrigenous sequences: an update. APPEA J 31:297

Powell TG, McKirdy DM (1973) Relationship between ratio of pristane to phytane, crude oil composition and geological environment in Australia. Nature 243:37-39

Raymond A, Murchison D (1991) Influence of exinitic macerals on the reflectance of vitrinite in Carboniferous sediments of the Midland Valley of Scotland. Fuel 70(1):155-161 
Raymond R, Andrejeko MJ (1983) Mineral matter in peat: its occurence, form and distribution. Los Alamos National Laboratory Report LA9907 OBES

Sawlowicz Z (1993) Pyrite framboids and their development: a new conceptual mechanism. Geol Rundsch 82:148-156

Sýkorová I, Pickel W, Christanis K, Wolf M, Taylor GH, Flores D (2005) Classification of huminite-ICCP System 1994. Int J Coal Geol 62(1-2):85-106

Taylor GH, Teichmüller M, Davis A, Diessel CFK, Littke R, Robert P (eds) (1998) Organic petrology. Gebrüder Borntraeger, Berlin, Stuttgart, ISBN 978-3-443-01036-2

Tissot BP, Pelet R (1981) Sources and fate of organic matter in ancient sediments.In: Oceanologica acta, special issue actes 26 th congres international de geologie.

Tissot BP, Welte DH (1984) Petroleum formation and occurrence. Springer-Verlag, Berlin Heidelberg GmbH

Togunwa OS, Wan Hasiah A (2017) Geochemical characterization of Neogene sediments from onshore West Baram Delta Province,
Sarawak: paleoenvironment, source input and thermal maturity. Open Geosci 9(1):302-313

Wan Hasiah A (2003) Coaly source rocks of NW Borneo: role of suberinite and bituminite in oil generation and expulsion. Bull Geol Soc Malaysia 47:153-163

Ward CR, Li Z, Gurba LW (2006) Variations in elemental composition of macerals with vitrinite reflectance and organic sulphur in the Greta Coal Measures, New South Wales. Australia Int J Coal Geol 69(2007):205-219

Wilkins RWT, George SC (2002) Coal as a source rock for oil: a review. Int J Coal Geol 50:317-361

Ying LS (2010) Source rock evaluation and characterisation of reservoir analougue of Miri and Lambir Formations, Sarawak. Unpublished undergraduate thesis.

Publisher's Note Springer Nature remains neutral with regard to jurisdictional claims in published maps and institutional affiliations. 